\title{
Menteşe Bey’in İsmi, Menşe’i ve Menteşeoğulları'nın Vakıflarına Dair
}

\author{
Vedat Turgut*
}

On the Name and the Origin of Menteshe Beg and the Waqfs

Abstract $\square$ Menteshe Beg gave his name to the beylik founded in ancient Caria region from the last quarter of XIIIth century. Nearly any results have been obtained from the studies regarding the name and the origin of Menteshe Beg and from where they came to that region. The information that Byzantine historian Pachymeres had given regarding that Menderes Turks had helped Osman Gazi could not be understood clearly due to the perception of that beyliks were independent from each other. Therefore the dimensions of the struggle made by the Turks against Knights Templar for Rhodes Island could not be comprehended easily. This study binds the origin of Menteshe Beg to the Kayir/Kir Khan, the leader of Khwarezmians who took service with Seljukids after the Battle of Yassıçemen in the light of waqf documents and shows that the beylik had come to that region from the vicinity of Sakarya River. Besides, the data about Sasan Beg who had significant role on the conquest of Western Anatolia was assessed. The possibility of that Kayir Khan bound Western Anatolia Beyliks and the Ottomans under his leadership by means of his other sons aside from Menteshe Beg makes us think that Khwarezmians that lost their state after Mongol invasion and battle of Yassıçimen took a principal role for the foundation of a global state. The fact that the name of Kayir Khan's father was Nu'man may show that not only Karesioğulları but also many of governing class of beyliks had relation with Danishments. On that sense this study can be regarded as the first step of the attempt to reframe the matter of the Turkification of Western Anatolia.

Keywords: Menteshe Bey, Numan oğlu Kir Bey, Kayir Han, Khwarezimshah, Danishments.

* Bilecik Şeyh Edebali Üniversitesi. Maddi ve manevi katkılarından dolayı VAKAR’a teşekkür ederim. 
Menteşe Bey'in menşe'i konusunda başta Wittek ve Uzunçarşılı olmak üzere tarihçiler tarafından yapılan tetkiklerden kesin bir neticeye ulaşılamamıştır. Wittek, önemli değerlendirmelerde bulunduğu eserini, Pachymeres ve Chalcocondyles gibi Bizans, Hammer'den naklen Vertot'un St. Jean Şövalyeleri tarihi hakkındaki eserinde bulunan bir pasaj dolayısıyla Batılı ve nihâyet Yazıcızâde Ali, Enverî, Eflâki ve Şikâri gibi Doğulu müelliflerin eserlerine dayandırır. ${ }^{1} \mathrm{O}$, Menteşe Bey'in bölgeye nereden geldiği ve babasının kimliği hakkında değişik rivâyetler üzerinde durduktan sonra, bunların tenkide muhtaç olduğunu belirtirken, Uzunçarşılı da Menteşelilerin ibtidalarının kat’i olarak bilinemediğinin altını çizer. ${ }^{2}$ Aile şeceresi hakkında en güvenilir belge olarak bir kitâbeyi gösteren Wittek ve Uzunçarşıll, Ahmed Gazi'nin 1391 tarihli mezar taşındaki şu bilgilere dikkat çekerler: "Ahmed Gazi ibn İbrahim ibn Orhan ibn Mesud ibn Menteşe ibn Ablistan ibn Karabey/Kuru Bey”. Wittek kitabedeki üst ata ismini Kara, Uzunçarşılı ise Kuru şeklinde okumuştur. Dikkat edilirse Uzunçarşılı ve Wittek, faaliyetleri hakkında hiçbir bilgiye sahip olmadıkları ailenin üst atasının ismini okuma konusunda yazıdaki bozukluğa bağlı olarak ihtilafa düşmüşlerdir. Wittek, Menteşe isminin sadece bir kitâbede bulunup diğer belgelerde olmamasından hareketle ismin sonradan idhal edilmiş olabileceğinden başka, Elbistan'ın bir yer ismi olması dolayısıyla ailenin menşeinin buradan çıkmış olabileceğini düşünmektedir. ${ }^{3}$ Bu yazıda evkâf tahrir defterlerindeki bazı kayıtlar üzerinden Menteşe Bey'in soyunun Kayır (Kır) Han'a dayandığı, dolayısıyla Batı Anadolu beylikler dünyasının Harzemşahlar ile yakın bağları bulunduğu gösterilmeye, beyliğin tarihi gelişim süreci de buna uygun olarak yorumlanmaya çalışılacaktır. Pachymeres tarafindan "ikinci Kudüs" olarak tavsif edilen bölgenin fatihi Sasan Bey'in türbe vakfı ile ilgili kayıtlar da aşağıda ele alınacak olan tesbitleri tamamlayıc bir öneme sahiptir.

Pachymeres'in eserinde zikrettiği Mantachias ve "cesur" manasına geldiğini belirttiği Salampakis, iki ayrı kişi olarak ele alınmıştır. Salampakis’ in "Sahil Beyi”"

1 Paul Wittek, Menteşe Beyliğgi, çev. O. Ş. Gökyay, Ankara: Türk Tarih Kurumu, 1999), s. 48-52; İ. Hakkı Uzunçarşılı, Anadolu Türk Tarihi Vesikalarından II. Kitap, Kitabeler, (İstanbul: Devlet Matbaası 1347-1929), s. 168-177; Uzunçarş11, Anadolu Beylikleri ve Akkoyunlu, Karakoyunlu Devletleri, (Ankara, Türk Tarih Kurumu Yayınları, 2011), s. 70-71; Uzunçarşıl1, "Menteşeoğulları”, IA, VII, s. 727.

2 Wittek, Menteşe Beyliği, s. 48-52; Uzunçarşılı, Anadolu Beylikleri..., s. 70; Uzunçarşılı, "Menteşeoğulları", s. 724.

3 Wittek, Menteşe Beyliğgi, s. 40-52, 56vd; Uzunçarşı1l, Kitabeler, II, s. 169-177; Uzunçarşı1lı, Anadolu Beylikleri..., s. 70-83; Uzunçarşıl1, "Menteşeoğulları", s. 725. 
manasında Menteşe Bey'in unvanı olduğuna yönelik Wittek tarafından ortaya konan görüş, kabul görmüşe benzemektedir. Ancak, Pachymeres'in manasını da verdiği Salpakis/Salampakis'in Süleyman Bey şeklinde anlaşılması da pek tabiidir. ${ }^{4}$ Öte yandan okunaksız mezar taşından dolayı Kara/Kuru şeklinde takdim edilen şahsın adının Kır Bey/Kır Han (Kayır Han) şeklinde okunması, Menteşe Bey'in köklerini, aynı adı taşıyan ve 1230 'da Yassıçemen savaşından sonra Alaeddin Keykubad'a sığınan Harzemşahlara mensup emirlerden Kırhan/Kayır Han'a dayandırabilir. ${ }^{5}$ Bütün bu bağlantıları kurarken, Sakarya Nehri havâlisinde kurulmuş olan bazı vakıf kayıtlarından hareket edildiği belirtilmelidir. ${ }^{6}$ Söz konusu kayıtlarda Menteşe Bey ve kardeşi Süleyman Bey'in Bolu'daki Viranşehir'e bağglı Kırdivanı'nda Turbeyioğlu Umur Fakih'e yaptıkları vakıf kaydında baba adlarının da Kır Bey şeklinde geçmiş olması oldukça ilgi çekicidir. ${ }^{7}$ Burada hemen kitabedeki, Menteşe Bey'in en üst ata isminin Karabey/Kurubey şeklinde verildiği hatırlanmalıdır.

Bolu Sancağı Evkâf Defteri'nde münderiç kayıtlarda Kır Bey’in babasının ismi "Nu'man" olarak geçer. ${ }^{8}$ Kır Bey'in bölgenin fethindeki önemi, bir divana isminin verilmiş olmasından anlaşılır. Bu divanın, defterde bazen "Kayır Divanı" şeklinde verilmesi önemli açılımları beraberinde getirmektedir. ${ }^{9}$ Numanoğlu Kır $B e y$ 'in de Bolu'ya bağlı Gerede ve Bender-i Ereğli'de iki adet vakıf kaydında ismi geçmektedir. Gerede'de muhtemelen oğlu olan İsmail ile beraber Çağa Cuma Camii hatibi için 131 akçe hâsıllı bir zemin vakfeden Kır Bey, Ereğli’de bir çiftlik ve beş adet zemini Mevlana Hüsameddin adına vakfetmiştir. ${ }^{10}$ Çankırı'ya bağlı Kurşunlu'nun Kır Han isimli bir köyünün bulunması da bu bağlamda önemlidir. Kır Han Köyü’nde Hacı Murad-ı Veli soyundan gelen ve Seyyid Mahmud

4 Pachymeres, Bizanslı Gözüyle Türkler, haz. İ. Biter Barlas, (İstanbul: İlgi Yayınları 2009), s. 59, 100-101; Wittek, Menteşe Beyliğgi, s. 29-30.

5 Kayırhan ve bağlantılar konusunda ayrıca bkz. F. M. Emecen, İlk Osmanlılar ve Batı Anadolu Beylikler Dünyası, (İstanbul: Timaş Yayınları, 2016), s. 27-28, 42-43.

6 Konunun özeti için bkz. Vedat Turgut, "Batı Anadolu Beyliklerinin Menşei Meselesi”, Sakarya Üniversitesi Sosyal ve Kültürel Araştırmalar Dergisi, 2/3 (Nisan 2016), s. 55-89.

7 TADB. TTD. EV. 547, v. 93b.

8 Bender-i Ereğli Nahiyesi'nde Numanoğlu Kır Bey tarafından vakfedilen çiftlik ve altı adet zeminden 255 akçenin hâsıl olduğuna dair kayıt için bkz. TADB. TTD. EV. 547, v. 213a; Turgut, "Batı Anadolu Beyliklerinin Menşei Meselesi", s. 65.

9 TADB. TTD. EV. 547, v. 27 b.

10 TADB. TTD. EV. 547, v. 72b-73a, 213a; Turgut, "Batı Anadolu Beyliklerinin Menşei Meselesi”, s. 66. 
Hayrâni ${ }^{11}$ ile bir bağı bulunan Elvan Seydi Zaviyesi adına bir vakıf kaydı yer alır. ${ }^{12}$ Keza Konyåda Kır-âbâd ve Kır-İli şeklinde kaydedilen nahiye, Alaüddin Keykubâd zamanında hizmete alınan Harzem Emiri Kayır/Kır Han'ın etki sahasının Selçuklu başkentine kadar uzandığını gösterir. ${ }^{13}$ Giresun-Bulancak ve Piraziz taraflarında da Kayırhan isminde bir köyün varlığı, ${ }^{14}$ bu isimle anılan yerleşim birimlerinin ne kadar geniş bir alana yayıldığının en önemli göstergesidir. Teke Sancağı dâhilinde "Sultan" Korkud'un vâlidesi Nigar Hatun tarafindan vakfedilen bir köyün adının da Kayır olduğuna değinilmelidir. Bu köyde bazı yerlerin umerâdan Budak Bey ${ }^{15}$ tarafından da vakfedildiği görülmektedir. ${ }^{16}$ Aşık Paşa’nın yerleştiği dönemde Gülşehri olarak da anıldığı belirtilen Kırşehri'nin adının ${ }^{17}$ da Kayır Han'dan esinlenildiği üzerinde düşünülmelidir. Burada ele alınması icâb eden diğer bir kayıt, Kütahya Sancağı dâhilinde yer alan Uşak’taki Kuzucuk nâm-ı diğer Kayırhan adlı köyün Ahi Seydi Ahmed'in atası Ahi Seyyid Mustafa için Aydınoğlu İsa Bey tarafından vakfedildiğine dairdir. Söz konusu vakıf daha sonra

11 Anadolu’nun çeşitli yerlerinde adına çok sayıda zaviyeler kurulmuş olan Mahmud Hayranî̀nin neredeyse bütün menâkıbnâmelerin ortak bir siması olarak sunulduğunu belirtmek yanlış olmaz. Bu bakımdan, müstakil bir çalışma olarak ele alınması daha doğru olacaktır.

12 TADB. TTD. EV. 578, v. 102b. Şeyh Elvan Zaviyesi'ne ait dört müdlük yerden 140, imamete meşrut iki müdlük yerden ise 130 akçe hâsıl sağlandığı anlaşılmaktadır. Elvan Seydi’nin Mahmud Hayrânî evladından olduğuna dair rivâyetler Osmanlı belgelerine dahi yansımıştır. İki önemli zâta dair Anadolu'nun pek çok yerinde vakıflar yapıldığı anlaşılmakta olup, Elvan Seydi'nin Mehmed Neşrî̀nin Cihannümâ’sında Geyikli Baba’nın tarikâtinden olduğunu belirttiği kişi olması çok önemlidir. Aşıkpaşazâde'de Ebu'l-Vefa şeklinde verilen bu bilgi, Barkan tarafından "Seyyid Ebu Elvan" şeklinde verilmişse de sonradan buna pek dikkat edilmemiştir. Bkz. Mehmed Neşri, Cihannüma, I, haz. F. R. Unat-M. A. Köymen, (Ankara, Türk Tarih Kurumu Yayınları, 1995), s. 168-169; Ö. L. Barkan, “Osmanlı İmparatorluğu’nda Bir İskân ve Kolonizasyon Metodu Olarak Vakıflar ve Temlikler I: İstila Devrinin Türk Dervişleri ve Zâviyeleri”, VD, II (1942), s. 290; Osmanlılar ve Anadolu beyliklerinin Elvan Seydi, Mahmud Hayrânî ve Hacı Murad-ı Veli üzerinden Vefâiyye, Yeseviye ve Bayezid-i Bistâmî ile olan bağlantısı ayrı bir çalışmanın konusudur.

13 TADB. TTD. EV. 564, v. 5a, 7a; Ö. L. Barkan, “Osmanlı İmparatorluğu’nda Bir İskân”, s. 329.

14 Feridun M. Emecen, Doğu Karadeniz’de İki Kıyı Kasabasının Taribi, Bulancak-Piraziz, (İstanbul: Bahçeşehir Üniversitesi Yayınları, 2015), s. 42, 87, 90, 121, 126, 137, 175, 246.

15 Budak Bey’in adına Çankırı Sancağı Evkâf Defteri'nde de rastlanır. Bkz. TADB. TTD. EV. 578, v. 99a.

16 TADB. TTD. EV. 567, v. 15b, 37a; Behset Karaca, Teke Sancağı,(Isparta: Fakülte Kitapevi, 2010), s. 369-370.

17 İlhan Şahin, "Kırşehir”, DİA, 25, s. 481; Elvan Çelebi, Menâkıbül-Kudsiyye fi Menâsıbüll-Ünsiyye, haz. İsmail E. Erünsal-A. Yaşar Ocak, (Ankara, Türk Tarih Kurumu Yayınları, 1995), s. 102. 
Germiyanoğlu Süleymanşah Çelebi ile oğlu Yakub Çelebi tarafindan da muaf/ müsellem tutulmuştur. ${ }^{18}$

Kır Bey’in Menteşe Bey, Süleyman Bey, Mehmed Bey, Kemal (Kemaleddin İsmail) Bey ve Seyfi (Seyfeddin) Bey adlarında beş oğlunun olduğu yine vakıf kayıtlarından anlaşılmaktadır. ${ }^{19}$ Bunlardan 1261 yılında Batı Anadolu'da önemli bir uç gazisi olarak tebârüz eden Gazi Mehmed Bey ile aynı kişi olması muhtemel olan Kır oğlu Mehmed Bey, Mustafa Seydi adına Bender-i Ereğli'de 12 çiftlik yeri vakfetmiştir. Aynı vakıf için Toman Bey (Osman Gazi? $)^{20} \mathrm{de}$ biti vermiştir. ${ }^{21}$ Kır oğlu Seyfi Bey ise, Gerede’ye bağlı Taceddin Divanı'nda 126 akçelik bir yeri Bayezid Fakı'nın atası Dündar için vakfetmiştir. Buradaki Seyfi'nin, Ahi Evran'ın adına "Menâhic-i Seyfi"22 adlı eseri te'lif ettiği Kırşehir Valisi Seyfeddin Tuğrul olması kuvvetle muhtemeldir. ${ }^{23}$ Kemal Bey ise, Mudurnu’ya bağlı Fınducak Köyü'nde 15 müdlük yerden hâsıl olan 373 akçeyi Mustafa ve Mehmed adına vakfetmiştir. ${ }^{24}$ Burada zikredilen Kemal Bey’in yukarıda Kır Bey ile beraber vakıf kurduğu belirtilen İsmail ile aynı kişi olduğu düşünülebilir. Kemaleddin İsmail Bey, Selçukluların hizmetinde arzü’l-ceyş

18 TADB. TTD. EV. 560, v. 233b.

19 Bolu Evkâf Defteri'nde "Kayır oğlu İbrahim Bey" elindeki yerin, Yıldırım Bayezid tarafından vakfedildiğine dair olan kayıt da son derece önemlidir. "Karye-i Muslibiddin .... Kayır oğlu İbrahim elinde dutadutduğu yerini Bayezid Hüdâvendigâr vakf itmiş. İsfendiyar zamanında 15 müdlük yerdir. İmdi Mevlana Alaüddin Fakih mutasarrıfdır, yılda iki hatim okuya deyû mukayyed der defter-i atîk. Haliyâ İsa Fakih mutasarnf bâ-berât-ı cedid-i âlişan.”. bkz. TADB. TTD. EV. 547, v. 168b. Bu kayıt, Kayır Bey’in en erken Murad Hüdâvendigâr veya Orhan Gazi döneminin yerel beylerinden biri olduğunu düşündürür. Ancak Anadolu'nun pek çok yerinde Kayır Han’ın ismi ile müsemma yerleşim birimlerinin varlığı göz önüne alındığında, Kayır Han’ın isminin parlatılmasının gerekliliği geçerliliğini korur. Bolu’da tesbit edilen bu kayıt dışında, "Kıroğlu" şeklinde kaydedilen diğer beyler üzerinden Anadolu beyliklerinin menşei meselesini çözümleyebilmek de ihtimal dahilinde görünür.

20 Konu hakkında bkz. V. Turgut, “Osman Gazi’nin Kimliği ve Cihanşümûl Bir Devlete İsminin Verilmesinin Sebepleri Üzerine”, Akademik İncelemeler Dergisi, II/1 (2016), s. 83-120.

21 TADB. TTD. EV. 547, v. 207a; Turgut, "Batı Anadolu Beyliklerinin Menşei Meselesi”, s. 68. Gazi Mehmed Bey’in Aydınoğulları ve belki Germiyanoğulları'nın atası olabileceği fikri, ayrı bir çalışmada ele alınacaktır.

22 M. Ali Hacıgökmen, "I. Alaeddin Keykubat Dönemi Emirlerinden Atabey Bedreddin Gühertaş (Gevhertaş) (D?-Ö. 1262), Ankara Üniversitesi, DTCF Tarih Araştırmalar Dergisi, XXX/50 (2011), s. 126.

23 TADB. TTD. EV. 547, v. 64b; Turgut, "Batı Anadolu Beyliklerinin Menşei Meselesi”, s. 70.

24 TADB. TTD. EV. 547, v. 232b-233a. 
görevini ifa ederken, 1277 yılında Memlük Sultanı Baybars'ın eline geçen Selçuklu ricâli arasında zikredilir. ${ }^{25}$

Menteşe Bey'in Menderes havalisine deniz tarafindan değil, ${ }^{26}$ Sakarya Nehri'nin doğusundan geldiğini gösteren diğer bir kayıt da Menteşe Bey’in veya onun oğlu Kirman'ın damadı olup, Efes, Tire, Birgi, Piriene ve Ayasuluğ'u (Efes) ilk defa fetheden Sasan Bey'in türbe vakfıdır. Menteşe Bey'in damadı olan Sasan Bey hakkında kaynaklarda verilen bilgiler oldukça sınırlıdır. ${ }^{27}$ Sasan Bey'in türbesi için Bolu’daki Gökçesu Köyü’nde 439 akçe hâsılı olan bir zeminin vakfedildiği görülmektedir. ${ }^{28}$ Burada türbenin köyde olup olmadığı bilinmemekte olup, zeminin sadece bir akârâtı gösterdiği de düşünülebilir. Hüdâvendigar Sancağı'na bağlı Yarhisar'da "sâbıkan karye" olduğu belirtilen Sasan isminde bir mezrânın da bulunduğuna burada değinilmelidir. ${ }^{29}$ Sasan Bey’e bağlı olan Türkmenlerin Sasan Bey'in ölümünden sonra Rumeli'nin fethi sırasında Süleyman Paşa’nın emrinde faaliyet gösterdikleri, Süleyman Paşa’nın Bolayır'daki vakıf köylerinden birinin “Sasanî/Sasanlar” ismini almasından hareketle söylenebilir. Menteşe Sancağı

25 Osman Turan, Selçuklular Zamanında Türkiye, (İstanbul: Boğaziçi Yayınları, 1998) s. 412, 474, 546; İbn Bibi, El-Evâmirül-Alầiyye fi'l-Umûri'l-Alâ’iyye, Selçuknâme, çev. Mürsel Öztirk, (Ankara, Türk Tarih Kurumu, 2014), II, s. 464, 566-568; Baybars, Baypars Tarihi, çev. M. Şerefüddin Yaltkaya, (Ankara, Türk Tarih Kurumu Yayınları, 2000), s. 86.

26 İ. Hakkı Uzunçarşılı, Anadolu Beylikleri..., s. 70; Uzunçarşılı, "Menteşeoğulları”, s. 724.

27 İlk Osmanlı kaynaklarından Enverî, Aydınoğlu Mehmed Bey'den önce Menderes havâlisinin Menteşe Bey'in damadı Sasan Bey/Sasa Bey adındaki bir gazi tarafından fethedildiğini haber verir. Enverîde verilen bu bilgileri, Pachymeres gibi Bizans kaynakları da teyid eder. Wittek, fetihler sırasında Tire'den Girit’e kaçan bir kâtibin, Sasan Bey adındaki bir "İranlı" tarafından Efes'in 1304 'te ele geçirildiğini belirttiğinden bahseder. Menteşe Bey’in ölümünden sonra Sasan Bey’in müstakil bir şekilde hareket etmeye başladığı düşünülebilir. Rodos'un fethini müteakib kısa süre içinde şövalyelerin eline geçmesi hadiseleri sırasında Sasan Bey'in Aydınoğlu Mehmed Bey ile mücadeleye giriştiği bilinmektedir. Bunun için bir süre Hıristiyanlarla ortak hareket eden Sasan Bey’in sonunda yine Onlara karşı gaza ederken mağlub olarak hayatını ve beyliğini yitirdiği belirtilmektedir. Enverî, Düsturnâme, haz. M. Halil Yinanç, İstanbul: Türk Tarih Encümeni Külliyatı, 1928), s. 17; Wittek, Menteşe Beyliği, s. 32-43; Pachymeres, Bizanslı Gözüyle Türkler, s. 76-77, 100-101; Nicolae Jorga, Osmanlı İmparatorluğu Tarihi, Çev. Nilüfer Epçeli, (İstanbul: Yeditepe Yayınları, 2005), V, s. 68; Himmet Akın, Aydınoğulları Tarihi Hakkında Bir Araştırma, (Ankara: Ankara Üniversitesi DTCF Yayınları, 1968), s. 21-26; Uzunçarşılı, "Menteşeoğulları”, s. 724 .

28 TADB. TTD. EV. 547, v. 25a; Turgut, "Batı Anadolu Beyliklerinin Menşei Meselesi”, s. 67.

29 TADB. TTD. 80, v. 218a; BOA. TD. 23, s. 107; Vedat Turgut, Osmanl Devleti'nin Kurulus Coğrafyasinda Vakıflar ve Şehirleşme (16. yy. Bilecik ve Çevresi), (Bilecik: Bilecik Şeyh Edebâli Üniversitesi Yayınları, 2015), s. 196, 260. 
içinde Bozüyük, Söğüdözü, Söğüdcük gibi yer isimleri de ailenin bölgeye Sakarya Nehri'nden indiklerini düşündürür. ${ }^{30} \mathrm{Bu}$ noktada isimlerin onomastik açıdan değerlendirilmesi, durumu çok daha farklı bir noktaya ulaştırabilir.

\section{Onomastik Bir Tartışma}

Kır Bey/Kayır Han'ın baba isminin Nu'man olarak kaydedildiğine yukarıda değinilmişti. "Nưman" ismi, "kan" ve kan gibi kırmızı olduğu için "gelincik çiçeğì manasına gelir. Bu bağlamda ismi, "kana dayalı soy", "asalet" manasında değerlendirmek de mümkündür. ${ }^{31}$ Nu'man adı, "toprak" manasında "berr" ile beraber kullanıldığından Hz. Ali'nin "Ebĥu Tûrab” unvanını anımsatır. Tarihte Nu'man ismiyle bilinen önemli şahsiyetlere bakılacak olursa, ilk akla gelen İmâm-1 Âzam Ebu Hanife Nu’man bin Sabit'tir. Yine Seyyid Danişmend Gazi etrafında gaza faaliyeti ile meşgul olarak Anadolu'nun Türkleşip Müslümanlaşmasında önemli hizmetleri dokunan Süleyman b. Nu’man önemli bir şahsiyet olarak karşımıza çıkar. ${ }^{32}$ Turtûşî̀ nin Siracül-Müllukk adlı siyasetnâmesinde geçen Numan b. Münzir bir diğer örneğimizdir. ${ }^{33} \mathrm{Hac}$ Bayram Veli'nin asıl adı da Nu'man bin Ahmed'dir. ${ }^{34}$ Anadolu'da Elbistan'a yerleşip burada adına vakıflar te'sis edilen Dede Kargın/Ğarkın'ın esas isminin de Nu’man olduğu son zamanlardaki

30 VGMA, Defter: 990, Sayfa: 160, Sıra: 158; BOA. TD. 12, s. 224; BOA. TD. 75, s. 398; BOA. TD. 434, v. 208a; BOA. TD. 490, s. 493; BOA. MAD. 2, s. 32a-b. Ayrica bkz. TADB. TTD. EV. 569.

31 Burada asil kandan kastın Hz. Ali ve dolayısıyla Hz. Muhammed'e mensubiyet olduğu düşünülmelidir.

32 Danişmend Gazi Destânı’nın bu önemli kahramanları hakkında bilgi için bkz. Danişmend Gazi Destanı, haz. Necati Demir, (Ankara, Hece Yayınları, 2006). Aşağıda Kayır Han ile olan bağlarını tartışacağımız beyliklerin, Danişmend Gazi’nin hatırasına saygı duyduklarını düşündüren önemli bir kayıt hakkında bkz. TADB. TTD. EV. 571, v. 55. "Karye-i Güllüce tabi-i Birgi. Vakf-ı Umur Bey ve İsa Bey ber evlad-ı Tayî Seydi ve ber muceb-i ahkâm-ı Sultan Mehmed Han mescid-i mezkûrun evlâdına meşrût olup ve hâliyâ padişahımız berâtıyla mutasarrıf olup müstehak mahal olan bunlardır ki zikrolunur. (Sekiz nefer evlad-1 vakıf)". Defterin transkripsiyonu için bkz. M. Akif Erdoğru, Kanuni Sultan Süleyman Devri Aydın İli Evkâf Defteri (Metin ve İnceleme), İzmir 2016, s. 74. Kastamonu'da da "Tayi Sultan” adına kurulan zaviye için önemli miktarda akarat vakfedildiği görülmektedir. Bkz. TADB. TTD. EV. 554, v. 25a-26a, 119b; TADB. TTD. EV. 555 , v. 169b-170a, 228a, 233a. Danişmend Gazi’nin babasının adının Seyyid Toylu Taylu Danişmend olduğu hakkında bilgi ve vakıfları için için bkz. Osman Turan, Selçuklular Zamanında Türkiye, s. 112-117.

33 Muhammed b. Turtûşî, Siracül-Mülûk, haz. Said Aykut, (İstanbul, İnsan Yayınları, 2005), s. 233. 34 Nihat Azamat, "Hacı Bayram Veli", DIA , 14, s. 442-447. 
araştırmalarda ortaya konulmuştur. Nưman Dede'nin Baba İlyas Horasanî ve Hacı Bektaş Velî̀nin mürşidi olduğu tahmin edilmektedir. ${ }^{35}$ Bu noktada Menteşe Bey'in baba adının "Ablistan" şeklinde okunduğunu hatırlamakta fayda vardır. Dede Ğarkın Nu’man'ın, hem Kır Bey, hem de Baba İlyas ile bağlantılı olduğunu düşünmek için diğer önemli sebebimiz, Kır Han’ın öldürülmesinin ardından Baba İlyas İsyanı'nın patlak vermesidir. ${ }^{36}$ Dolayısıyla, Kır Bey’in ölümünün Babaî İsyanı'na zemin hazırlayan koşullardan biri olmasından öte, isyanın direkt sebebi olarak önerilmesi daha mâkûl görünmektedir. ${ }^{37}$ Buraya kadar örnekleri verilen şahsiyetlerin tamamının kökeni Acem/Pers coğrafyasına dayanmaktadır. Buradan Nu’man adının Acem ve Irak-ı Acem coğrafyasında sıkça kullanıldığı sonucu çıkarılabilir. Ayrıca Nu’man adına sahip olan bu önemli zâtların hemen hemen hepsinin "seyyid" olarak kaydedildikleri müşâhede edilmektedir.

Kır Bey ismi ise, "saygın, itibar sabibi genç" anlamında ele alınabilir. İsmin, Bizans imparatorları için kullanılan "kyr" ve eski İran kültüründe önemli bir yeri olan "kayra" kelimesiyle de yakından ilişkili olduğu düşünülebilir. Şöyle ki; "kyr" kelimesi taht, taht sahibi manasında olup, bir anlamda hâkimiyet kaynağını Tanrı'dan alan kişiler için kullanılırdı. "Kayra" kelimesi, yüksek tutulan veya sayılan birinden gelen lütuf, inâyet manasına gelmektedir. Bu anlamıla evrendeki bütün olayları ilahî sebebe dayandıran, insanların ancak "Tanrı" kayrasıyla kurtulabileceğini ileri süren "providansiyalist" öğretinin Türkçedeki karşıllı̆ının da "kayracılık" olarak önerildiğini belirtelim. Bu durumda ismin anlamı "Allah'ın seçtiği, dilediği kimse" dir. Koruma, himmet anlamlarıyla "kayırmak" kelimesi de "kayra"dan türemiş olabilir. Bu düşünceden ve Bolu Sancağı'nda bir divanın bazen "Kır" bazen ise "Kayır" şeklinde yazılmış olmasından hareketle Harezmli ünlü kumandan Kayır Han ile Kır Bey’in aynı kişiler oldukları dahi tahmin edilebilir. Sözlüklerde "kayır", "iri taneli kum türü" olarak tanımlanmaktadır. Bu anlamıyla Kayır isminin de Nu’man faslında açıklandığı üzere "Ebu Turâb" ile bağlantılı olduğu düşünülebilir. Celalzâde Salih Çelebi’nin, Süleyman Paşa’nın Rumeli’deki

35 Ahmet Y. Ocak, Ortaçă̆ Anadolu'sunda İki Büyük Yerleşimci (Kolonizatör) Yahut Vefâiyye ve Yeseviyye Gerçeği: Dede Garkın ve Emirci Sultan (13. Yüzyıl), (Ankara: Gazi Üniversitesi Yay, 2011), s. $45-46$.

36 Elvan Çelebi, Menâkıbül-Kudsiyye fi Menâsıbüll-Ünsiyye, s. XLI; Ahmet Y. Ocak, Dede Garkın ve Emirci Sultan, s. 45-46; Turan, Selçuklular Zamanında Türkiye, s. 420-427.

37 Babaî İsyanı hakkında geniş ve çeşitli bilgiler için bkz. A. Y. Ocak, Babailer İsyanı, Aleviliğin Tarihsel Alt Yapısı Yahut Anadolu'da İslam-Türk Heterodoksisinin Teşekkülü̈, (İstanbul: Dergâh Yayınları, 2011); Turan, Selçuklular Zamanında Türkiye, s. 420-426; W. A. Gordlevski, Anadolu Selçuklu Devleti, çev. Azer Yoran, (Ankara: Onur Yayınları, 1988), s. 176-183. 
gaza faaliyetlerinden bahsederken, bölge halkının bu gaziler hakkındaki görüşlerini "bu kavm ki kavm-i Kayır gibi hep bayır ve sayır vesair emâkini tuttular..." şeklinde açıklaması da son derece ilgi çekicidir. Burada gazilerin kum taneleri gibi sayılamayacak kadar çok olduğu anlatılmaya çalışılmış olacağı gibi, Kayır Han'a bağlı Türklerin torunları oldukları bilincine de işaret ediyor olabilir. Kayır

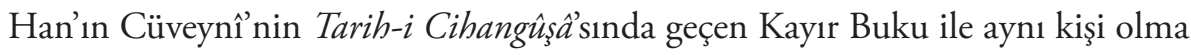
ihtimali de bulunmaktadır. Kayır Han, Harzemşah Celâleddin Mengüberti'nin Yassıçimen Savaşı'nda I. Keykubâd'a yenilmesinden sonra Tatvan ve civarında diğer Harezmli kumandanlar ile beraber konaklarken, Erzincan valiliği ile Selçuklu hizmetine alınmış, Keykubâd zehirlenerek öldürülmeden evvel onu Sivas valiliği'ne atamıştır. Onun Selçuklu hizmetine girmeden evvel Harzemşahların mı yoksa Eyyübîlerin mi hizmetinde olduğu kesin olarak bilinememektedir. Ancak Yassıçimen hezimetinden sonra Harzemlilerin onun etrafında toplanması ikinci ihtimâli zayıflatır. Veliahd tayin edilen İzzeddin Kılıçarslan’a bağlılığını son ana kadar korumaya çalışan ünlü kumandan, Sadedin Köpek'in etkisiyle Gryaseddin II. Keyhüsrev tarafından Kayseri Zamantı'daki (Pınarbaşı) hisara hapsedildi ve bir süre sonra burada vefat etti. Onun başına gelen bu olaylardan sonra Harezmliler, Selçuklu hizmetinden çıkarak güneye indiler ve Anadolu-Suriye ticaret yolunu sekteye uğratacak faaliyetlerde bulundular. Burada Eyyübîlerin birbirleriyle olan mücadelelerine de karışan ve 1241'de Kudüs'ün Haçlıların elinden yeniden alınmasında önemli roller üstlenen Harzemlilerin, daha sonra Batı Anadolu'da kurulacak olan beyliklerin temelini teşkil ettikleri anlaşılmaktadır. Harzemlilerle beraber Moğol İstilâsının önünden gelen Baba İlyas ve müridlerinin de Kır Bey’e revâ görülen bu olaydan sonra isyan bayrağı açtıkları kesindir. ${ }^{38}$ Bu görüşümüz, aşağıda tafsilatlı olarak ele alınacaktır.

38 Turan, Selçuklular Zamanında Türkiye, s. 378-380, 383, 389, 404-408, 417; Köprülü, Osmanl Devletinin Kuruluşu, (Ankara: Türk Tarih Kurumu Yayınları, 1991), s. 42; Emecen, İlk Osmanlılar ve Batı Anadolu Beylikleri Dünyası, s. 42-44, 171; Emecen, Osmanlı Imparatorluğu’nun Kurulus ve Yükseliş Tarihi, (İstanbul: Türkiye İş Bankası Kültür Yayınları, 2015), s. 23; Celâl-zâde Sâlih Çelebi, Hadîkatüss-Selâtinn, haz. Hasan Yüksel, H. İbrahim Delice, (Ankara: Türk Tarih Kurumu,2013), vr. 37b-38a/s. 42; C. Cahen, Anadolu'da Türkler, terc. Yildız Moran, (İstanbul, E Yayınları 1994), s. 139; Alaaddin Ata Melik Cüveynî, Tarih-i Cihan Güşâ, çev. Mürsel Öztürk, (Ankara, Türk Tarih Kurumu, 2013), s. 275, 279, 379-380; Mustafa Kılıç, "Celaleddin Harizmşah'tan Sonra Anadolu ve Suriye'de Harizmliler”, Eyyübiler, (Yönetim, Diplomasi, Kültürel Hayat), ed. Önder Kaya, (İstanbul: Küre Yayınları, 2012), s. 231-247; M. F. Köprülü, "Harzemşahlar", İA, V/I, İstanbul 1977, s. 290-292; Muammer Gül, "Harezmli Türklerin Anadolu ve Yakındoğu’daki Rolleri ve Tesirleri”, Belleten, LXX/257,(2006), s. 100-101; Hasan Geyikoğlu, "Anadolu’da Kalan Harezmliler (Horzumlular)", Türk Kültürü, 354/10 (1997), s. 53-54. 
Menteşe Bey'in isminin anlamı ve kökeni hakkında yapılan tartışmalardan ise, kelimenin Türkçe olduğu sonucu çıkmış gibi görünür. Kaynaklardaki Menteş Baba, Hacı Bektaş Veli'nin kardeşi Menteş ve Menteşe Bey gibi örneklerden hareketle yaygın olarak kullanıldığı görülen bu ismin, kapı ve pencereleri birleştirmeye yarayan Farsça bend-keşeden bozma olduğu fikri bir yana bırakılırsa, "benzer" kelimesinden türediği veya "ince altın ve gümüs bilezik" manasına gelen Türkçe bir kelime olduğu fikri öne çıkmıştır. Oysa Kır Bey’in çocuklarının isimleri incelendiğinde Kemal Bey (İsmail ), Süleyman Bey, Mehmed/Muhammed Bey ve Seyfi Bey'in dinî literatürden Arapça isimler olduğu aşikârdır. Daha önce P. Wittek'in de ortaya koyduğu üzere Menteşe isminin yazılışı "Menteşâ" imlâsıyla yani "elif" harfiyle olmuş, bunun "Menteşe" şeklindeki kaydı ise modern dönemlerin bir icadı olarak belirlenmiştir. ${ }^{39} \mathrm{Bu}$ konu hakkında, Türklerin Arap harfleriyle karşılaştıkları ilk dönemlerde "-e" ve "-a" seslerini "elif” harfi ile verdiklerine yönelik bir açılama, Menteşe Bey'in kardeşlerinin isimlerinin kökeni zaviyesinden bakıldığında yeterli değildir. Şu halde "Menteşâ”" isminin de Arapça olup olmadığı üzerinde durulmalıdır. Bu ismin Arapça "men" ve "teşa" kelimelerinin birleşiminden ortaya çıkmış olması kuvvetle muhtemeldir. Bu kelimelerin Âl-i İmran sûresinin 26. ve 27. ayetlerinde beş defa geçtiği müşahede edilmektedir. Ayet aynen şöyledir: "Kulillabümme mâlike'l-mülki tu'tell-mülki men teşâü ve tenziül-mülke minmen teşäü ve tuizzu men teşâü ve tuzillu men teşaü bi-yedike'l-hayr, inneke alâ külli şeyin kadir. Tûlicu'l-leyle fi'n-nehâri ve tûlicu'n-nehâr fi'l-leyl ve tuhricül-hayya mine'l-meyyiti ve tuhricül-meyyite mine'l-hayy ve terzuku men teşâü bi gayrı hisâbin"; meâlen: "De ki: Ey Mülkün sahibi Allah’im, dilediğine mülk verirsin ve dilediğinden de mülkü çeker alırsin ve dilediğini aziz edersin ve dilediğini zelil edersin! Hayr yalnz senin elindedir, muhakkak ki sen her şeye kaadirsin. Geceyi gündüzün içine sokarsin ve gündüzü gecenin içine sokarsın ve ölüden diri çıkarrrsın ve diriden ölü çıkarırsın ve dilediğine de hesapszz rzzk verirsin." "40 Gerek Selçuklu ve gerekse Osmanlılarda cülûs sırasında okunan ayetlerin başında gelen bu ayetlerdeki "men teşâ" kelimesi "Allah’ın dilediği kimse" manâsında ele alınabilir. Ayetlerin anlamı, "melikül-umerâ" olan Menteşâ Bey'in mülk yani egemenlik sahibi bir aileden gelmesinden dolayı, isminin Arapça kökenli olabileceği açıklamasına bir üstünlük kazandırır. Ayrıca ismin bu anlamı, babası Kayır Han’ın isminin anlamıyla da örtüşür.

39 Wittek, Menteşe Beyliği, s. 26-28.

40 Âl-i İmrân Sûresi, 3/26-27. Bkz. Elmalılı Hamdi Yazır, Kur'anı Kerim ve Meali, haz. Dücane Cündioğlu, (İstanbul: İslamoğlu Yayıncılık, 1993), s. 52. Men teşa kelimesi, aynı anlamlarda olmak üzere birçok ayette "men yeşâ" ve "men-neşâ" şeklinde de verilmiştir. 


\section{Kuruluş ve "Osmanlılaşma"}

Menteşe Bey'in Karia (Muğla ve civarı) bölgesini tam olarak ne zaman fethettiği tesbit edilememektedir. Ancak İmparator VIII. Mihail'in kardeşi Johannes'i Menderes havalisine gönderdiği 1269 yılında Karia’nın sahil limanları olan Strobilos, Stadia ve Trachia bile çoktan Türklerin eline geçmişti. Bu limanlar, Uzunçarşılı tarafından bölgenin Türklerin eline geçmesinde istinad noktası olarak gösterilmişse de Wittek, bu görüşe karşı çıkmıştır. Onun bu görüşündeki haklılığını Sakarya Nehri civarındaki vakıf kayıtları açık bir şekilde göstermektedir. ${ }^{41}$ VIII. Mihail 1278 'de bu defa oğlu Andronikos'u Menderes havalisine gönderdiğinde Karia ve Antiochia’nın sonunun çoktan geldiğine şahit oldu. Kaystros, Priene, Milet ve Magedon Türkler tarafından alınmıştı. Yeni tahkim edilmiş olan Tralles (Aydın) "cesur" manasına gelen Salampakis (Süleyman Bey) ve Mantachias (Menteşe Bey) tarafından kuşatıldığında şehir halkı açlık ve susuzluğa sonuna kadar direndiler. Susuzluklarını gidermek için sahip oldukları hayvanların damarlarını keserek kanlarını içen şehir halkı, bu suretle ölen hayvanlarının etiyle açlığa bir nebze dayanabilmişlerse de susuzluğa dayanamayacaklarını anlayınca Türklere bir harabe bırakmak niyetiyle şehri surlarıyla beraber yıkmaya başladıkları sırada kırıldılar. Şehrin komşusu Nyssa (Sultanhisar) da aynı akıbete uğradı. ${ }^{42}$ Menteşe Bey'in tam olarak ne zaman öldüğü bilinmemektedir. Ancak onun Uç’ları dizginlemek için harekete geçen Moğol-Selçuklu güçlerinin bir seferi sırasında şehid edildiği ve kabrinin Fethiye'de olduğu rivâyeti vardır. ${ }^{43}$ Bu sıralarda VIII. Mihail, Müslümanlara katılmak için deniz yoluyla Kırım'dan hareket eden Koutzimpaxis'in bir kaza sonucu Bithynia'ya düşmesiyle mürted olup, kendi hizmetine girmesini siyasetine uygun görmüştü. O, muhtemelen Kır Bey'in oğlu Süleyman Bey'in kızıyla Koutzimpaxis’in evlenmesini sağlayarak Müslümanların akınlarını durdurma planları yapıyordu ${ }^{44}$ Ancak Türklerin kendilerini zafere taşıyacak bir lider bulma konusunda hiç zorluk çekmedikleri anlaşılıyor. Nitekim Bithynia sınırında Sakarya Nehri havâlisinde faaliyet gösteren Osman Gazi, çevresine çok sayıda alp-gazi toplayabilen karizmatik bir lider olarak ortaya çımıştı. Öyle ki

41 İ. H. Uzunçarşılı, Anadolu Beylikleri..., s. 70, Uzunçarşılı, "Menteşeoğulları", s. 724; Wittek, Menteşe Beyliği, s. 26.

42 Pachymeres, Bizanslı Gözüyle Türkler, s. 59-60; Wittek, Menteşe Beyliği, s. 26; Uzunçarş1l,,

"Menteşeoğulları", s. 724-725; Erdoğan Merçil, "Menteşeoğulları”, DİA, 29, s. 152.

43 BOA. TD. 338, s. 130; Ahmet Yiğit, XVI. Yüzyıl Menteşe Livası Vakıfları, (Ankara: Barış Platin, 2009), s. 101.

44 Pachymeres, Bizanslı Gözüyle Türkler, s. 76-77; Turgut, "Batı Anadolu Beyliklerinin Menşei Meselesi”, Sakarya Üniversitesi Sosyal ve Kültürel Araştırmalar Dergisi, 2/3 (2016), s. 68. 
Menderes havalisinden dahi Osman Gazi'nin akınlarına yardım etmeye gelen gaziler, 1302 yılındaki Bapheus (Koyunhisar) Savaşı'nda General Mouzoloun'un Osman Gazi'ye yenilmesinde önemli rol oynadilar. Bu zaferden sonra Sakarya Nehri'nin batısına akın yapmayı bir süredir durdurmuş olan Umur Bey'in oğlu Ali Bey ve Nusret Bey, ${ }^{45}$ Osman Gazi ile ortak hareket etmeye başladılar. Bu ortaklık müteakip yıllarda Ali Bey’in oğlu Şahin Bey’in Paşa unvanı ile Orhan Gazi’nin oğlu Murad Hüdâvendigâr'a "lala" olmasıyla daha üst noktalara taşınacaktır. ${ }^{46}$ Pachymeres'e göre Türkler, Anadolu'nun batısına gruplar halinde dağılıyor ve düşmanlara düzensiz görünen savaş taktiğiyle etrafa korku salıyorlardı. ${ }^{47}$

Osman Gazi'nin liderliğindeki Türkler de Bursa, İznik ve İzmit'e giden yolları tutarak şehirleri açlık ve susuzlukta teslim olmaya zorluyordu. Bizans imparatoru'nun, 1304 yllında Sgouros komutasında gönderdiği ordu da Osmanlılar tarafından bozguna uğratıldı. Germiyanoğlu Alişir, bu sıralarda Denizli'de bulunan Tripolis’i ele geçirmiş ve akınlarını Philadelphia’ya (Alaşehir) kadar uzatarak şehri kuşatmıştı. Menteşe Bey'in damadı Sasan (Sasa) Bey ise, Menderes'ten Efes'e kadar olan sahil mıntıkasını fethetmişti. Sasan Bey'in ortaya çıkışı, imparator adına Menderes bölgesini ele geçirdikten sonra hükümdarına karşı isyan eden Alexios Phlantrop’un ölümünün ardından olmuştur. Tire'yi açlığa ve susuzluğa mahkûm ederek ele geçiren Sasan Bey, Efes'e de anlaşma yoluyla hâkim olmuş ve çevresinde toplanan gazilerle Menteşe Bey'den bile daha güçlü hale gelmişti. ${ }^{48}$

Osmanlılar ile ortak hareket eden Kır Bey oğlu Menteşe Bey ve damadı Sasan Bey' in ${ }^{49}$ Sublaion üzerindeki tahkimatın zayıflamasından bi'l-istifade Rodos'u hedef yapacak olan fetihleri gerçekleştirmiş oldukları görülüyor. Esasen, 1284 yılında Bizans donanmasının techizâtının ekonomik sebeplerden dolayı karşılanamayarak

45 Bursa'nın fethine katılan ve Okçu Baba diye anılan Murat Paşa’nın Karacabey (Mihaliç̧)'de de vakıfları vardır.

46 Pachymeres, Bizanslı Gözüyle Türkler, 72-77; Halil İnalcık, Kuruluş Dönemi Osmanlı Sultanları, (İstanbul: İSAM Yayınları, 2010), s. 32-34; Turgut, "Vakıf Belgeleri Işı̆̆ında Umur Bey ve Lala Şahin Paşa’nın Menşei ve Osmanlılar ile İttifakına Dair”, Osmanlı Araştırmaları, 47 (2016), s. 5.

47 Pachymeres, Bizanslı Gözüyle Türkler, s. 80.

48 Wittek, Menteşe Beyliği, s. 38-44; M. Çetin Varlık, Germiyanoğulları Tarihi, (Ankara: Sevinç Matbaası, 1974), s. 38-39; İnalcık, Kuruluş Dönemi Osmanlı Sultanları, s. 34-38.

49 Sasan/Sasa Bey'in Batı Anadolu'daki faaliyetleri hakkında bkz. S. Runciman, "Anadolu'nun Ortaçağlardaki Rolü”, Belleten, VII/27 (1943), s. 550; Donald Edgar Pitcher, Osmanl Imparatorluğu’nun Tarihsel Coğrafyası, çev. Bahar Tırnakçı, (İstanbul: Yapı Kredi Yayınları, 1999), s. 53-59; İ. H. Uzunçarşılı, Anadolu Beylikleri..., s. 104; Uzunçarşılı, Kitâbeler...,II, s. 117; Himmet Akın, Aydınoğulları Tarihi...., s. 21-27. 
lağvedilmesi, Türk denizcilerinin Ege Denizi'nde serbestçe hareket etmesine olanak vermiş ve bu denizdeki en önemli adaların başında gelen Rodos'un iç kale dışındaki her yeri 1300 yılında Türklerin eline geçmişti. Chios/Sakız Adası da sık sık Türk akınlarına mâruz kalıyordu. 1304 yılına kadarki bu hızlı Türk fütûhâtına karşı Bizans imparatoru, Roger de Flor'un komutasındaki Katalan Bölüğü’nü hizmetine aldı. Kapıdağı'ndan yola çıkan Katalanlar, önlerine çıkan Karesi Türkleri'ni mağlub ettikten sonra Germiyan, Saruhan, Aydın ve Menteşe Türklerini de bozguna uğratarak bölgedeki Türk fetihlerini kısa süreliğine sekteye uğrattılar. Liderleri Roger'in öldürülmesinden sonra Katalanlar, Balkanlarda kendilerine katılan Türkopollerle beraber Bizanslılar aleyhinde faaliyete başladılar. Öte yandan, kutsal topraklardan kovulduktan sonra mallarına el koyulan Tapınak Şövalyeleri'nin yerine ön plana çıkarılan Hospitaliers, St. Jean Şövalyeleri adıyla Rodos'u kendilerine merkez yapmak gayesiyle 1306 yılında adayı Türklerden aldılar. Rodos'u ele geçirmek için 1310 yılında harekete geçen Türk donanmasının başında kimin olduğu tam olarak anlaşılamasa da seferin başarısız olduğu bilinmektedir. ${ }^{50}$ Şövalyelerin bu başarısı Tapınak Şövalyeleri’ne ait mülklerin kendi tarikatlarına bağışlanmasını sağlad. ${ }^{51} \mathrm{Bu}$ mücadeleler sırasında Aydınoğlu Mehmed Bey'in daha önce müşterek hareket ettiği Sasan Bey'in elindeki yerleri ele geçirerek kendi beyliğini kurduğu anlaşılmaktadır. Sasan Bey’in ele geçirdiği yerlerin, Kayır Han soyundan gelmediği için kendisinde kalmadığı söylenebilir. Kayıroğlu’na damat olan Sasan Bey’in, yine bir Kayıroğlu olması kuvvetle muhtemel olan Mehmed Bey'e fethettiği yerleri kaptırdığı düşünülebilir. Aydınoğulları’nın ve -belki- Germiyanoğulları’nın Kayır

50 XVII.-XVIII. Yüzyıl Batılı tarihçileri, 1310 yılındaki bu Rodos Seferi'nin başındaki Türk büyüğünün Osman Bey olduğunu ileri sürmektedirler. Bkz. Ziver Bey, Rodos Tarihi, çev. Harid Fedai, Ankara, Türk Tarih Kurumu, 2013), s. 51; Wittek, Menteşe Beyliği, s. 55; İ. Hami Danişmend, İzahlı Osmanlı Tarihi Kronolojisi, (İstanbul: Sümer Kitabevi, 1971), I, s. 8; Enverî, Düstûrnâme, Medhal, haz. M. H. Yınanç, (İstanbul, Devlet Matbaası, 1932), s. 17, 22. Rene Aubert Vertot, Historie de Chevaliers Hospitaliers, (Paris 1737), II, s. 101 vd.; 1772 baskısı için bkz. https://books.google.com.tr/books?id=HF9WAAAAYAAJ\&printsec=front cover\&dq=Histoire + des + Chevaliers + Hospitaliers + de + S. + Jean + de $+J \% C 3 \% A 9$ rusalem + volu me+2\&hl=fr\&sa=X\&ved=0ahUKEwj Fw8i3zrDQAhULax QKHfJ_ASYQ6AEIPzAE\#v=on epage \&q\&f=false.

51 Tapınak Şövalyeleri, Katalanlar ve Hospitaliers’lerin kutsal topraklardan kovulmalarından sonraki faaliyetleri için bkz. Yusuf Ayönü, Katalanların Anadolu ve Trakya'daki Faaliyetleri, (13021311), (İzmir: Ege Üniversitesi Yayınevi, 2009); Zachariadou, "The Catalans of Athens and the Beginning of the Turkish Expansion in the Aegean Area", Studi Mediavali, XXI/3 (1980), s. 821-838; Zachariadou, "Atina Katalanları ve Ege Bölgesinde Türk Yayılmasının Başlaması", çev. Serdar Çavuşdere, TAD, 45 (2009), s. 235-254; Ebru Altan, "Templier ve Hospitalier Şövalye Tarikatlarının Kuruluşu”, Belleten, LXVI/245, s. 87-94. 
oğlu Mehmed Bey (Gazi Mehmed Bey) ile birbirlerine bağlanması, fetihlerde "kavm-i Kayır" önderliğini belirginleştirir. ${ }^{52}$

Pachymeres, Menteşe Bey'den Germiyanlı olarak bahsediyor ki bu, el-Ömerîde bulunan Menteşe ve Aydınoğulları'nın Germiyanoğulları'na tâbi olduklarına yönelik söylemi destekler. ${ }^{53}$ Menteşe Bey'in ölümünden sonra halefi olan damadı Sasa(n) Bey'den başka Kırman ve Mesud adlarında iki oğlu tesbit edilmiştir. Sasan Bey'in Kırman'ın damadı olması da muhtemeldir. Bundan başka 1400 yılında vefat ettiği bilinen ve türbesi Selçuk'ta (Efes) bulunan Menteşe oğlu Hacı Umur'un Menteşe Bey'in evlâdından olduğu belli ise de hangi kolundan geldiği bilinememektedir. Hacı Umur, ismini Bolu'da bir kahraman olarak tanınan Lala Şahin Paşa'nın atası Umur Bey'den esinlenilerek almış olmalıdır. ${ }^{54}$ Menteşe Sancağı'nda bir kestaneliği vakfeden Menteşeoğlu Turud Fakih'in de Menteşe Bey'in oğlu olup olmadığı konusunda da henüz net bir şey söylemek mümkün değildir. ${ }^{55}$ Menteşeoğulları'nın asıl toprakları olan Muğla, Balat, Milas, Beçin, Bozöyük, Marin, Çine, Tavas, Pırnaz, Megri (Fethiye) ve Köyceğiz’in idaresi ise Mesud Bey'in elindeydi. 1300 yılında Rodos'u ele geçiren Türk donanmasının Mesud Bey'in emrinde olduğu kanaati hâkimdir. Mevlanânın torunu Ulu Arif Çelebi ile yakın ilişki kurduğu bilinen Mesud Bey’in tesbit edilebilen iki oğlunun isimleri İbrahim ve Orhan Bey'dir. ${ }^{56}$

Orhan Bey, Osman Gazi'nin oğlu Orhan Gazi ile çağdaş olduğundan kimi zaman birbirlerine karıştırılmıştır. İki Orhan’ın da İbrahim adında oğulları vardır ve taşıdıkları unvanlar dahi aynıdır. Orhan Bey, Rodos'u geri almak için giriştiği seferlerle meşhûrdur. Milas ve Beçin’de yaptırdığı camilerin kitâbesinde unvanı "Şücaüddin" olarak belirlenen Orhan Bey' in yanında "El-Harezmı̀"! adında büyük bir âlimin bulunduğu ve hükümdar ile arasına giren soğukluğun giderilmesi konusunda İbn Battuta’dan aracılık istediği anlaşılmaktadır. "Emir-i Kebir" unvanı

52 Bu bağlantı ayrı bir çalışmada tafsilatlı olarak ele alınacaktır.

53 Pachymeres, Bizanslı Gözüyle Türkler, s. 100; Şihabeddin b. Fazlullah el-Ömerî, Türkler Hakkında Gördüklerim ve Duyduklarım, Mesâliküll-Ahbar, çev. D. Ahsen Batur, (İstanbul: Selenge Yayınları, 2014), s. 160-162; İbn Fadlullah el-Ömeri, Mesâliküll-Ebsâr fî̀ Memâliki'l-Emsâr, (Thk. Kâmil Süleyman el-Cubûrî), (Beyrut: Dar Al-Kutub Al-İlmiyah, 2010), III, s. 222.

54 Wittek, Menteşe Beyliği, s. 42-43, 94; Turgut, "Vakıf Belgeleri Işı̆̆ında Umur Bey ve Lala Şahin Paşa'nın Menşei...”, s. 1-19; Uzunçarşı1ı, "Menteşeoğulları”, s. 725, 727, Uzunçarşı11, Anadolu Beylikleri", s. 71, 83.

55 TADB. TTD. EV. 569, v. 112a.

56 Wittek, Menteşe Beyliği, s. 56-57; Uzunçarşılı, Anadolu Beylikleri, s. 71-72; Uzunçarşılı,

"Menteşeoğulları", s. 725; Merçil, "Menteşeoğulları”, s. 152. 
ile anılan Orhan Bey'in kızını Aydınoğlu Süleymanşah ile evlendirdiği ve İbrahim Bey adındaki oğlunun da Ahmed Gazi, Mehmed Bey ve Musa Bey adlarında üç oğlu olduğu bilinmektedir. ${ }^{57}$ İbrahim Bey, donanmasının Venedik tazyikine uğraması sonucunda, onlarla Balat'ta bir kilise kurulması ve konsolos ikâmesi konusunda anlaştı. Onun ölümünden sonra oğullarından Musa Bey, Mehmed Bey ve Ahmed Bey kendilerine ait bölgelerde hüküm sürmeye başladılar. ${ }^{58}$ Rodos Şövalyeleri ve Kıbrıs kralı ile muharebelerde bulunan Ahmed Gazi'nin beyliğin pek çok yerinde vakıf eserleri bulunmaktadır ki buna aşağıda değinilecektir. ${ }^{59}$

Kosova Savaşı'ndan sonra Yıldırım Bayezid'in Anadolu harekâtı sırasında Ahmed Gazi vefat etti ve Mahmud Bey'in elindeki yerler Osmanlı topraklarına katılırken, helalleşmek amacıyla Bergama Kazası'ndaki bazı yerler kendisine mülk olarak verildi. ${ }^{60}$ Onun, Candaroğlu İsfendiyar Bey' in yanına kaçmasından sonra, mülk köyünün İlyas Bey’in vârisleri tarafından tasarruf edildiğine bakılırsa, İlyas Bey'in belki de Mahmud Bey'in oğlu olduğu sonucuna varılabilir. Ancak, Mahmud Bey’in kardeşiyle aynı adı taşıyan bir oğlunun olabileceği de düşünülmelidir. ${ }^{61}$ Latinlere karşı gaza faaliyetleriyle meşgul olan İlyas Bey, ${ }^{62}$ Çelebi Mehmed'in duruma hâkim olmasından sonra bağımsızlığını kaybetti. Bunun en önemli göstergesi Şövalyelerin İzmir'deki kalelerinin yıktırılmasına karşılık Menteşeili'ndeki Bodrum'a (Halikarnas/Petromion) kale yapmalarını buyuran Çelebi Mehmed'in hükmüne karşı çıkmamasıdır.. ${ }^{63}$ Onun Çandarlı İbrahim Paşàya bir köyü temlik etmesi, Çelebi Mehmed ile İlyas Bey arasındaki ilişkinin

57 Wittek, Menteşe Beyliği, s. 57-69; Uzunçarşılı, Anadolu Beylikleri, s. 72-74; Uzunçarşılı, "Menteşeoğulları", s. 725-726; İbn Battuta, Seyahatnâme, çev. A. Sait Aykut, (İstanbul: Yapı Kredi Yayınları, 2000), I, s. 411-412; Merçil, “Menteşeoğulları”, s. 152.

58 Wittek, Menteşe Beyliği, s. 68-71; Uzunçarşılı, Anadolu Beylikleri, s. 74-76; Uzunçarşı1ı, "Menteşeoğulları", s. 726-727; Merçil, "Menteşeoğulları", s. 152.

59 Wittek, Menteşe Beyliği, s. 87-90; Uzunçarşılı, Osmanlı Tarihi, I, Ankara 2015, s. 309-316; Uzunçarşıl1, Kitabeler, II, s. 158; Uzunçarşılı, "Menteşeoğulları”, s. 728; Merçil, "Menteşeoğulları”, s. 153.

60 "Karye-i Çöki, Bayezid Hüdâvendigâr Menteşe ili istihlâli için Mahmud Bey’e temlik etmiş...”. "Karye-i Değirmencik ki Tepecük demekle meşhûrdur, merhûm Bayezid Hüdâvendigâr Menteşe oğlu Mahmud Bey’e istihlâl için mülklüğe vermiş...”. BOA. TD. 453, v. 53b, 54a, 60a; Uzunçarşı11, Anadolu Beylikleri, s. 76; Uzunçarşıl1, "Menteşeoğulları", s. 727-728.

61 TADB. TTD. EV. 580, v. 135b-136b.

62 İlyas Bey hakkında bilgi için bkz. Feridun M. Emecen, İlk Osmanlılar ve Batı Anadolu Beylikler Dünyası, s. 223-232.

63 Wittek, Menteşe Beyliği, s. 97; Uzunçarşıl1, Anadolu Beylikleri, s. 79; Uzunçarşıl1, "Menteşeoğulları”, s. 730 . 
boyutlarını daha da belirginleştirir. ${ }^{64}$ Hekim Mehmed Şirvânînin, onun adına "İlyasiye" adını verdiği bir tıp kitabı te'lif ettiği bilinmektedir. Mahmud oğlu Hekim Mehmed'in daha sonra Osmanlı hizmetine girdiği Balkanlar'daki vakıflarından anlaşılır. ${ }^{65}$

\section{Menteşeoğulları'nın Vakıfları}

Menteşeoğulları'nın hayrâtına dair vakfiyelere günümüzde maalesef ulaşılamamaktadır. Sadece Ahmed Gazi'nin Milas'taki tımarı ve cami evkâfı içinde yer alan bazı mahalleri işaret eden ibareler, Hacı Ömer Ağazâde Hacı İsmail Ağa Vakfiyesi içinde yer almaktadır. Buradan da vakfın akaratı hakkında malûmat edinmek mümkün değildir. ${ }^{66}$ Bununla beraber Menteşe Sancağı mufassal evkaf defterlerinde Menteşeoğullarından İbrahim Bey, Ahmed Gazi, Mehmed Bey’in oğulları Mahmud Bey ve İlyas Bey'in hayratlarına ait akar kayıtlarına ulaşılabilmektedir. Menteşe Bey'in kardeşi Süleyman Bey ile Bolu Sancağı'nda bir vakıf için verdiği bitiye yukarıda değinilmişti. Ayrıca Menteşe Bey'in Fethiye'deki (Mekri) türbesine ait akar kaydına göre, türbe için çeşitli mahallerde vakfedilen 17 parça yerden hâsıl olan 5,5 müd mahsulden sağlanan 400 akçeyi Hamza Fakih'in tasarruf ettiği tesbit edilebilmektedir. ${ }^{67}$ Menteşe Bey'in oğlu Orhan Bey'in Milas'ta Hacı İlyas Mahallesi'nde Selahaddin Camii olarak bilinen küçük camii ve Peçin'de Ahmed Gazi medresesi karşısında yine bir camii bilinmekle beraber, evkaf defterinde bunlara dair herhangi bir kayda rastlanılmamaktadır. Orhan Bey’in oğlu İbrahim Bey'in Balat'taki camii için vakfettiği akarattan ise toplam 4080 akçe hâsıl olduğu anlaşılmaktadır. ${ }^{68}$ İbrahim Bey'in oğlu Ahmed Gazi'nin Menteşeili'nin birçok yerinde vakıflar tesis ettiğine yukarıda değinilmişti. Onun Balat'ta yaptırdığ mevlevihâne zaviyesi için çeşitli yerlerde vakfettiği akarattan toplam 4000 akçe hâsıl sağlandığı kaydedilmiştir. ${ }^{69}$

64 BOA. TD. 338, s. 12-13; Yiğit, Menteşe Livası Vakıfları, s. 24, 125-126.

65 Wittek, Menteşe Beyliği, s. 99-104; Uzunçarşılı, Osmanlı Taribi, I, s. 56-57; Uzunçarş1l, Anadolu Beylikleri, s. 80-82; Uzunçarşıl1, "Menteşeoğulları", s. 730-731; Turgut, Yitirilen Mirasımız: Balkanlarda Kurulan Osmanlı Vakıfları (Fethinden XVI. Yüzyılın Sonuna Kadar), (Eskişehir: Türk Dünyası, 2016), s. 273; TADB. TTD. EV. 548, v. 203b; TADB. TTD. EV. 561, v. 292b.

66 VGMA, D. 618/1, s: 167, sira: 129.

67 BOA. TD. 367, s. 130, krş. Ahmet Yiğit, Menteşe Livası Vakıfları, s. 101; TADB. TTD. EV. 569, s. 89.

68 Uzunçarşılı, Anadolu Beylikleri, s. 73; BOA. TD. 367, s. 15 ve Ahmet Yiğit, Menteşe Livası Vakifları, s. 26, 127.

69 BOA. TD. 367, s. 14, 17, krş. Ahmet Yiğit, Menteşe Livası Vakıfları, s. 25, 126-127, 129. 
Ahmed Gazi'nin Peçin'de bina ettirdiği medrese, imaret ve camii ile Milas'taki camii için vakfettiği akarattan ise XVI. yüzyılın ortalarında toplam 70.468, yüzyılın sonlarında ise 73.928 akçe hâsıl sağlandığı hesaplanmaktadır. Söz konusu hâsılın Peçin'e bağlı Bozcaöyük, İsravalos’a tâbî Karaova, Mekri'ye tâbi gebran cemaati, Köyceğiz'deki günlük ağaçları mahsulü, Peçin hamamı ve serhânesi, Yıva Köyü'ndeki çeltik arkı ile Bozcaöyük Köyü’ndeki Akdoğan ve Ağaçluöyük çiftlikleri, Tekürnabar'nda ve Bozcaöyük Korusunda birer pâre yer ve Peçin Ovası'nda 10 pâre yer, Varvil Tuzlası'ndan 7,5 müd tuz geliri, Balat'taki hamam-1 cedid mukataası ve Acısu'da iki pâre yerden sağlandığı anlaşılmaktadır. Milas yağhânesinde camilerden yakılmak üzere 6,5 batman yağın yanısıra Marmaris Limanı'ndan senelik 7500 akçelik gelir de vakfedilmişken, limandan sağlanan gelirin daha sonra kesildiği belirtilmektedir. Vakıf karyelerden Bozcaöyük'ün, XVI. yüzyılın ortalarında 36 neferden müteşekkil nüfusundan vakıf için 9682 akçe sağlanırken, bu meblağın yüzyılın sonlarına doğru 10 neferden sağlanan 9600 akçeye düştüğü anlaşılmaktadır. Peçin Ovası'nda mütemekkin olan 93 neferden sağlanan 26.400 akçelik gelir, yüzyılın sonlarında 26.433 akçe olarak kaydedilmiş, cemaatin nüfusu ise 78 nefere düşmüştür. Karaova Köyü’nün nüfusu da 132 neferden 77 nefere düşerken hâsılı 4343 akçeden 4300 akçeye yuvarlanmıştır. Mekri'ye tâbi gebran cemaatinin nüfusu ise 7 neferden 14 nefere yükselmiştir. Köyceğiz "günlük" ağacından hâsıl olan 8000, Peçin'deki hamam kıstından hâsıl olan 1420, serhâneden hâsıl olan 435, çeltik arkından hâsıl olan 12.000, yukarıda zikredilen çiftlikler ve çeşitli yerlerden 3455, Varvil Tuzlası'ndan toplam 4600, Balat'taki cedid hamam mukataasından 100 akçe, vakfin diğer akar kalemleri arasında kaydedilmişlerdir. Vakfın hâsılından 5000 akçe bâkıyye kalırken, yüzyılın sonunda gelir fazlasına rastlanmamaktadır. ${ }^{70}$

Defterde vakfın masraf kalemleri de ayrıntılı olarak verilmiştir. Vakıf hâsılının Karaova, Varvil tuzlası ve Peçin hamamı gelirlerinden elde edilen 8863 akçesi mütevelli ve câbiye ayrılmıştır. Müderris için tayin edilen cihet yevmî 15 akçeden 50, senevî 5400 akçeden 18.000 akçeye yükseltilmiş olup, ilk sayımda İbrahim ikinci sayımda ise Ali müderris olarak kaydedilmiştir. Vakfın nezâreti de müderrise meşrut olup, bu cihetten ayrılan 720 akçenin yanı sıra birer müd hınta ve şa ir de tedris ciheti olarak kaydedilmiştir. Talebe için ayrılan mikdar ise yevmî beş akçeden senevî 1800 akçe olarak tesbit edilmiştir. Bundan başka Peçin Camii imameti için yevmî 4, senevî 1440; 10 nefer huffâzı için yevmî 10, senevî 3600;

70 BOA. TD. 367, s. 41-48, krş. Ahmet Yiğit, Menteşe Livası Vakıfları, s. 51-57; 155-160; TADB.

TTD. EV. 569, s. 1-7. 
Ahmed Gazi'nin türbesinde görevli 15 nefer eczâhan için senevî 8100; Peçin ve Milas Camii ser-mahfili için yevmî birer; Peçin ve Milas Camii ta’rifi için yevmî birer; Peçin Camii te'zini için yevmî üç, senevî 1080; Peçin Camii ve medresesi kayyumları için yevmî birer; tabbah için senevî 900; meremmetçi için yevmî bir; mu’id için yevmî bir; kitâbet için yevmî dört akçeden senevî 1440; Milas Camii imameti için yevmî üç, senevî 1080; yedi nefer huffâzı için senevî 2250; te'zin için yevmî bir; Peçin ve Milas camii noktacıları için birer; Milas Camii kayyımı için bir; meşihât için iki; türbedâr için senevî 180; rakabe için ise 1440 akçe cihet tayin edildiği anlaşılmaktadır. Milas'taki eski hamam kıstından hâsıl olan 100 akçe de hitâbet için ayrılmış olup, buna Peçin memlehâsı salyanesinden 800 akçenin zammolunduğu anlaşılmaktadır. Padişahın hassından da vakıf için senevî 1080 akçenin hitâbet ciheti için ayrıldığı kaydedilmiştir. Varvil Tuzlası'ndan ayrılan 800 akçe, Milas yağhanesinden yılda üç batman yağdan senevî 1440, Çine'deki bir harimden hâsıl olan 10 akçenin de eklenmesiyle hitâbet cihetine tayin olunan cihetin toplam 2134 akçeyi bulduğu hesaplanmaktadır. Peçin Camii hatibine de senevî 360 akçenin yanı sıra Menteşe Livâsı haslarından 1080 akçenin cihet tayin edildiği tesbit edilmiştir. İmaret ve medreseye müteallik damlara, suyolunu arıtmaya, anbar hıfzına ve ölçekçiye ayrılan senevî 270 ve imaret tabhına ayrılan senevî 12.600 akçe de vakfın masraf kalemleri arasında yer almaktadır. Yüzyılın sonunda vakfın gelirlerinden bâki olan miktarın 15.821 akçe olduğu anlaşılmaktadır. $^{71}$

Ahmed Bey'in Peçin nefsinde bir de mescid bina ettirdiği görülmektedir. $\mathrm{Bu}$ mescid için Acısu nâm-1 diğer Aytemür karyesinin gelirlerini vakfeden Ahmed Bey, 17 nefer ile mütemekkin olan köyden hâsıl olan 3550 akçenin 720 'şer akçesini tevliyet, cibâyet ve imamet, 360'ar akçesini te’zin ve eczâhana şart etmiştir. İmam için ayrıca Milas tahinhânesinden yevmî bir akçe tayin olunmuştur. ${ }^{72}$ Ahmed Gazi, Fethiye'de de bir cami ve medrese bina ettirmiş olup, bu hayrâtının Latinlerle yapılan mücadeleler esnâsında harab olması sebebiyle önce Hacı İvaz tarafından Seki Yaylası ve Üzümlü’de birer medrese halinde yenilendiği, bunların da harab olmasından sonra Hızır Bâli adında bir zâtın Döğer Kasabası’nda, Çalış adında diğer bir zâtın ise Seki Yaylası'nda vakfı yeniden ihyâ ettiği kaydedilmiştir. Medrese için Müderris nâm-ı diğer Arab arkı denilen çeltik arkından hâsıl olan

71 BOA. TD. 367, s. 41-48, krş. Ahmet Yiğit, Menteşe Livası Vakıfları, s. 51-57; 155-160; TADB.

TTD. EV. 569, s. 1-7.

72 BOA. TD. 367, s. 48, için Ahmet Yiğit, Menteşe Livası Vakıfları, s. 61, 160-161; TADB. TTD. EV. 569, s. 9. 
3500 akçenin yanısıra ikisi şehir kurbunda ve biri Seki'de olan üç yerden 110, Amas Köyü'nde bir bağdan 30, Dodurga'da Hacı Erbegioğlu demekle meşhur bir incir bahçesinden 30, Seki'de Atmaca bahçesi demekle maruf bir bahçe evi ve eşcârından 40 ve tuzla gelirinden senevî 1800 akçe olmak üzere toplam 5450 akçe vakfedilmiştir. Tuzla gelirinin daha önce 3600 akçe olduğu ayrıca belirtilmiştir. Seki'deki medrese hücreleri için Çalış tarafından Kirişburnu’nda yaptırılan hamamın harab olduğu ve hücreler için sadece Elviz Köyü'nde 600 akçe hâsılı olan bahçenin akar olarak kaydedildiği anlaşılmaktadır. Mekri (Fethiye) Camii için ise şehir içindeki iki pâre yerden hâsıl olan 200, Seki'deki bir pâre yerden hâsıl olan 100, balıktan 60, tuzladan 1680, Sevdik Köyü'ndeki bir bahçeden 200, Amas Köyü’ndeki iki dönüm bağ ve bir pâre diğer bağdan 130 akçe olmak üzere toplam 2370 akçe vakfedilmiştir. Tuzla gelirlerinden 360'ar akçenin hitabet, te'zin ve ser-mahfil, 300'er akçesinin ise muarrif ve kayyum için ayrıldığı kaydedilmiştir. Caminin aydınlatılması için Mekri yağhanesinden iki batman yağın verildiği de anlaşılmaktadır. ${ }^{73}$ Görüleceği üzere Ahmed Bey’in vakıfları bölgenin en büyük vakıfları arasında ilk sıralardadır. Sahip olduğu sosyo-ekonomik fonksiyonlarla bölgenin sosyal ve fiziki yapısında çok önemli bir yere sahiptir.

Hüdâvendigâr Livâsı'na bağlı olan Bergama'da vâki Değirmenciler nâm-1 diğer Depecük, Şüblüce ve Çöki köylerinin, Menteşeili’ndeki mülklerine karşılık Mahmud Bey'e temlik edildiğine yukarıda değinilmişti. Bu temlikin, Timur Vak'ası'ndan sonra mensûh olduğu görülmektedir. Osmanlıların vaziyete yeniden hâkim olmasından sonra tekrar mülk hâline getirilen köylerden Depecük demekle meşhûr olan Değirmenciler Köyü, Mahmud Bey’in kardeşi İlyas Bey'in vârisleri üzerine kaydedilmişken, Fatma Hatun vârislerinin Mahmud Bey'in vârislerinden hisselerini satın aldıklarını iddia etmeleri üzerine yapılan tahkikat sonucunda köyün 3/4 hissesi Fatma Hatun vârislerine, 1/4 hissesi ise İlyas Bey vârisleri üzerine tapulandırılmıştır. Fatma Hatun her ne kadar Uzunçarşılı tarafindan Mahmud Bey'in vârisleri olarak tanıtılsa da belgeden, köyün hisselerini Mahmud Bey’in vârislerinden satın alan kişi olduğu anlaşılmaktadır. Söz konusu hisseler, İlyas Bey'in vârisleri olan Hüsna? Paşa ve Sultan Paşa ile Fatma Hatun'un vârisleri olan Hamzaoğlu Emir Paşa ve Sultan Paşảdan Timurtaş Paşảnın oğlu Mustafa Bey'in oğlu Anadolu Beylerbeyi Kethüdâsı Mehmed Bey tarafından satın alınarak Bolu’da bina ettirdiği camiine vakfedilmiştir. Köyde meskûn olarak kaydedilen 70 neferden 3380 akçe hâsıl elde edildiği anlaşılmaktadır. Ahalisinin

73 BOA. TD. 367, s. 126-127, krş Ahmet Yiğit, Menteşe Livası Vakıfları, s. 101-102, 222-223; TADB.

TTD. EV. 569, s. 85, 90. 
perakende olmasından dolayı hariçten ziraat edilen ve 1400 akçe hâsılı bulunan Çöki Köyü de Mahmud Bey’in Timur'a iltica etmesinden sonra mensûh olmuş ancak daha sonra mülkiyeti mukarrer tutulmuştur. İlyas Bey'in vârisleri Şahi, Mahi ve Emir Paşa nâm hatunlar tarafından tasarruf edilen bu köy de Timurtaş Paşa'nın evlâdından Mehmed Bey'in Bolu'daki camiine vakfedilmiştir. ${ }^{74}$ Şıblüce Köyü ise Mahmud Bey'in vârisleri tarafından Bayezid Paşa'nın kardeşi Hamza Bey'e satılmış ve Hamza Bey de 1604 akçe hâsılı ile mukayyed olan köyü Bursa'daki imaretine vakfetmiştir. ${ }^{75}$

Ahmed Gazi'nin kardeşi Mehmed Bey'in oğlu Mahmud Bey’in oğlu olması muhtemel İlyas Bey'in de Menteşeili’nde çok sayıda vakfın altına imza attığı görülür. Onun Balat'ta bina ettirdiği medrese ve imareti için vakfettiği Bafa nâm-1 diğer Mersendükapu ve bu köye tâbi Mürted, Çukurcalu, İlisuluk, Karaviran, Amanlar ma’a Bademalanı ve Cullahlar, Alacalar ma’a Mandalyat, Değirmenderesi, Kızılkilise, Papaslık ve Bafa ile müteferrik cema'atten 27.390 akçe hâsıl sağlandığı anlaşılmaktadır. XVI. yüzyılın sonlarına gelindiğinde ise mezkûr köylerde meskûn bulunan yaklaşık 420 neferden 27.000 akçe sağlandığı hesaplanmaktadır. Burada hesabın kabaca yuvarlandığı tahmin edilebilir. Çerçin Köyü'nün hâsılı ise her iki sayımda da 23.000 akçe olarak hesaplanmıştır. Son sayımda köyün nüfusu perakende olanlarla beraber 212 neferdir. İlyas Bey'in vakfina bundan başka hâsılı 5000 akçe olan Balat hamamı ve şehir içinde müteferrik akarat kayıt altına alınmıştır. Vakfın toplam hâsılı yarım yüzyıllık zaman içinde 54.816 akçe ile 55.816 akçe arasında değişmektedir. Vakfın toplam masrafı ise her iki sayımda da 35.919 akçe olarak hesaplanmış olup, bâki kalan nakit akçenin 18.897 akçeyi bulduğu anlaşılmaktadır. ${ }^{76}$ Vakıftaki görevlilerinden her birinin cihetleri de ayrıntılı olarak gösterilmiştir. ${ }^{77}$

İlyas Bey'in Peçin nefsinde de bir medrese bina ettirdiği anlaşılmaktadır. $\mathrm{Bu}$ medresenin tasarrufunun Müderris Sinan b. Yakub'un elinde olduğu belirtilmekte ve vakfın toplam hâsılının 4125 akçeyi bulduğu hesaplanmaktadır. Toplam hâsılın 2625 akçesi Muğla nefsindeki hamamın 7/8'inden, 1500

74 BOA. TD. 453, v. 53b-54a, 60a; TADB. TTD. EV. 580, v. 135b-136b; Uzunçarş111, "Menteşeoğulları", s. 728.

75 TADB. TTD. EV. 580 , v. 141a-b.

76 BOA. TD. 367, s. 5-12, krş. Ahmet Yiğit, Menteşe Livası Vakıfları, s. 14-24, 119-125; TADB. TTD. 156, v. 75b-80a.

77 BOA. TD. 367, s. 5-12, krş. Ahmet Yiğit, Menteşe Livası Vakıfları, s. 14-24, 119-125; TADB. TTD. 156 , v. $80 \mathrm{a}-\mathrm{b}$. 
akçesinin Peçin'de müteferrik yerlerde bulunan 4.5 çiftlik yerden sağlandığı anlaşılmaktadır. Vakfın bir sehminin hâlâ mülk olduğu ayrıca belirtilmiştir. ${ }^{78}$ İlyas Bey'in Milas civarında bina ettirdiği zaviyesi için de 200 akçelik yerleri vakfettiği görülmüştür. ${ }^{79}$ İlyas Bey bundan başka Tavas'ta da bir zaviye bina ettirmiştir. Cafer bin Durali'nin tasarrufunda olduğu kaydedilen bu zaviye için Altunboğa Çiftliği, 1120 akçe hâsıliyla Paşacuk Köyü’nde 3.5 müdlük bağ ve 600 akçe hâsılı ile bir değirmen vakfedilmiş olup, toplam hâsıl 1720 akçe olarak hesaplanmıştır. ${ }^{80}$ İlyas Bey'in Mazon'a bağlı Hisarcık Köyü’nde bina ettirdiği caminin hitabet cihetine akar vakfettiğine dair kayıt da burada anılmalıdır. ${ }^{81}$ Mazon'da Şahin Bey'in değirmeninden hâsıl olanın nısfının da camide görevli olan hatibe şart olduğu belirtilmektedir. Değirmenin hâsılı ilk sayımda mukayyed değilken, ikinci sayımda 1100 akçe olarak belirlenmiştir. ${ }^{82}$ Onun Fethiye'de Ahi Saltık adına bina ettirdiği zaviye için de Fethiye'de 350 akçe hâsılı olan bir pâre yer ve Amas Köyü’nde 150 akçe hâsılı olan iki pâre bağı vakfettiği tesbit edilmektedir. Zaviyenin toplam hâsılı 500 akçe olup, Hacı Memi ve Mustafa tarafından tasarruf edilmektedir. ${ }^{83}$

İlyas Bey hakkındaki en önemli ve ilginç bilgi, Onun tarafından Osmanlı veziriazamı Çandarlı İbrahim Paşàya Balat’a bağlı Kızılöyük Köyü’nü temlik etiğine dair bilgidir. Temlik edilen bu köy, İbrahim Paşa’nın oğlu Çandarlı Halil Paşa'ya ve Ondan da oğlu Mahmud Çelebi'ye intikal ettikten sonra mensûh olmuş, Sultan II. Bayezid tarafından yeniden Mahmud Çelebi'ye verilmiş ve o da İznik’teki imaretine vakfetmiştir. ${ }^{84}$ Çandarlı İbrahim Paşảnın vakıflarına ait köy kayıtları bundan ibaret değildir. Onun Çine'ye tâbi Dalama nefsi ve Dalama’ya bağlı Eleklü, Güderenlü, Yortuç, Eymilli, Alacaatlu, Mesudlu ve buna bağlı Kuru,

78 BOA. TD. 367, s. 53, krş. Ahmet Yiğit, Menteşe Livası Vakıfları, s. 61-62, 164; TADB. TTD. EV. 569, s. 14.

79 BOA. TD. 367, s. 59, krş. Ahmet Yiğit, Menteşe Livası Vakıfları, s. 168; TADB. TTD. EV. 569, s. 20.

80 BOA. TD. 367, s. 115, krş. Ahmet Yiğit, Menteşe Livası Vakıfları, s. 95-96, 212; TADB. TTD. EV. 569 , s. 72.

81 BOA. TD. 367, s. 36, krş. Ahmet Yiğit, Menteşe Livası Vakıfları, s. 149.

82 BOA. TD. 367, s. 36, krş. Ahmet Yiğit, Menteşe Livası Vakıfları, s. 149; TADB. TTD. EV. 569, s. 113.

83 BOA. TD. 367, s. 131, krş. Ahmet Yiğit, Menteşe Livası Vakıfları, s. 106-107, 226; TADB. TTD. EV. 569 , s. 91.

84 BOA. TD. 367, s. 80-84, krş. Ahmet Yiğit, Menteşe Livası Vakıfları, s. 24, 125-126; TADB. TTD. 156 , v. $80 \mathrm{~b}-81 \mathrm{~b}$. 
Şehnâlu ve Kavacık köyleri ile Gireniz Cemaati'nden sağlanan gelirleri de İznik'teki evkafına vakfettiği görülmektedir. Her ne kadar bu köylerin İlyas Bey tarafından temlik edildiği belirtilmese de Kızılöyük Köyü için tesbit edilen durumun bu köyler için de geçerli olduğu düşünülebilir. ${ }^{85}$

\section{Sonuç}

Sonuç olarak, Menteşeoğulları'nın ibtidâlarının ve antik Karia bölgesine hangi cihetten ne zaman geldikleri hususunun açıklığa kavuşturulması vakıf belgeleri ile mümkün görünmektedir. Numan oğlu Kır Bey’in; Giresun, Çankırı, Bolu, Uşak, Denizli ve Antalya gibi Anadolu’nun birçok yerinde gerek Kır, gerekse Kayır namı ile anılan bazı köy ve divanlara isminin verilmesinden, Anadolu’nun uç bölgelerinin Türkleşmesinde çok önemli bir isim olarak öne çıktığı anlaşılır. Sayılan coğrafi birimler üzerinden çizilecek hat, Menteşeoğulları'nın Karia bölgesine geliş güzergâhlarını da belirler. Kayır Han'ın oğullarından olup, Pachymeres'in zikrettiği Menteşe Bey ve Süleyman Bey’in de Karia bölgesinin fethi için Sakarya Nehri civarından hareket ettikleri ortaya çıkar. Dolayısıyla Bizanslı müellifin kaydettiği Salampaksides bir unvan değil, ayrı bir şahsiyettir. Bolu'da Menteşe Bey’in damadı Sasan Bey'in türbe vakfıyla ilgili kayıt da bu tesbitleri kuvvetlendirmektedir. Böylece, Bafeus Savaşı sırasında Osman Gazi'nin etrafındaki Menderes Türkmenlerine dair aynı tarihçi tarafından verilen bilgi de daha anlaşılır bir hale gelmektedir. Bölgede vakıf kuran Kayır Han’n diğer oğullarının tarihi kimliklerini belirleme konusunda da bazı tahminler yapmak mümkündür.

Öyle anlaşılıyor ki, Kayır Han'ın Zamantı Kalesi'nde hapse atılıp ölüme terkedilmesinden sonra Anadolu'yu terk ederek Eyyûbilerin hizmetine giren Harzemliler, Kudüs'ün geri alınmasındaki önemli rollerinden sonra yeniden Selçukluların hizmetine girmişlerdir. Bunların torunları, Tapınakçı bakiyyelerinden olan Katalanların Batı Anadolu'daki rövanş mücadelesini bir şekilde savuşturmuşlar ve uçlardaki Türkleri teşkilatlandırarak kendileri için yeni yurtlar açacak fırsatı da bulmuşlardır. Dönemin olaylarını Memlük, İlhanlı veya Bizans zaviyesinden değerlendiren çağdaş kaynakların, Kayır Han ve mahiyetindeki Harzemlilerden çok az bahsetmiş olmaları, devletlerini yitirmiş olan bu kalabalık topluluğun güçlerini yeniden toparlayarak büyük bir cihan devletinin temellerini atacaklarını tahmin edememiş olmalarındandır. Osmanlı Devleti'nin

85 BOA. TD. 367, s. 130, krş. Ahmet Yiğit, Menteşe Livası Vakıfları, s. 78, 187-190; TADB. TTD.

156, v. 92a-94b. 
kuruluş sürecini ele alanlar tarafından sürecin oldukça mucizevî bulunması, bu durumu oldukça doğal kılar. Bununla beraber, Mevlana Celâleddin, Hacı Bektaş Velî, Baba İlyas Horasanî, Şeyh Edebali, Hacı Murad-ı Velî, Seyyid Mahmud Hayranî, Seyyid Elvan, Ahi Evrân, Tapduk Emre ve Yunus Emre gibi pek çok ulu şahsiyetin Moğol İstilası sonucunda Harzemlilerin inkırazıyla Anadolu’ya geldikleri de unutulmamalıdır. Köprülü’nün sarih bir şekilde ortaya koyduğu üzere, böyle cihanşümul bir devleti kurmak için gerekli olan siyasi, içtimâi ve etnik âmiller Anadolu coğrafyasında mevcuttu. Köse Mihal ve Gazi Evrenos gibi ihtidâ etmiş olan gazi aileler üzerinden esas âmil gücün Bizans ve Balkanların Slav aristokratlarından sağlandığına dair görüşleri, durumun ters-yüz edilmiş abartılı yorumları olarak değerlendirmek icab eder.

Menteşe Bey ve ailesinin antik Karia bölgesini ele geçirdikten sonra bölgedeki imâr faaliyetlerine hemen başladıklarını söylemek şimdilik mümkün değildir. Menteşeoğulları'ndan Ahmed Gazi ve İlyas Bey’in vakıfları, gelirleri en fazla olan ve dolayısıyla en büyük vakıflardır. Yıldırım Bayezid'in Anadolu seferleri sırasında Mahmud Bey’e Bergama'ya bağlı bazı köyleri vakfetmesi, cebren gerçekleştirdiği siyasete karşı oluşabilecek tepkileri dizginleyebilmek amacına matuftur. İlyas Bey'in Sadrazam Çandarlı İbrahim Paşa için temlik ettiği Kızılöyük Köyü de Şövalyelere İzmir mukabelesinde Bodrum'da kale yapmalarını emir buyuran Çelebi Mehmed'e bağlılık boyutlarının belirlenmesinde önemli bir yere sahiptir. Beyliklerin birbirleriyle olan bu yakınlığına dair vakıf belgelerinde bunun gibi pek çok örnek mevcuttur. Yukarıda belirtildiği üzere, Aydınoğlu İsa Bey’in, dedesinin ismini taşıyan Kayırhan Köyü'nde kurduğu vakıf bu cümledendir. Yine onun tarafından Murad Hüdâvendigâr'ın ruhuna Kur'an tilâveti yapılması için Kocaeli'de kurulan vakıf, Germiyanoğlu I. Yakub Bey'in oğlu Musa Bey’in Hamidoğulları'nın merkezi Eğirdir'de kurduğu mevlevihâne vakfı, Molla Şemseddin Fenâri için hem Teke Bey hem de Germiyanoğlu II. Yakub Bey tarafından verilen temliknâmeler ve Germiyanoğlu II. Yakub Bey’in Sadrazam Bayezid Paşa için verdiği temliknâme, Osmanlılar ve Batı Anadolu beylikleri arasındaki ilişkilerin son derece girift olduğunu göstermektediir ${ }^{86}$

86 TADB. TTD. EV. 560, v. 49a-50b; 53a, 233b; Afyon Müzesi, Kadı Sicilleri, No: 505/144; BOA. KK. 3357, s. 4; Süleyman Gönçer, "Değerli Bir Belge Bir Vakıfnâme”, Afyon Tasspınar Halkevi Mecmuası, 89-91/(1942), s. 110-113; M. Ç. Varlık, Germiyanoğulları Tarihi, s. 47-51; 


\section{Menteşe Bey’in İsmi, Menşe’i ve Menteşeoğullarinın Vakıflarina Dair}

Öz - XIII. yüzyılın son çeyreğinden itibaren Antik Karia bölgesinde kurulan beyliğe adını veren Menteşe Bey'in ismi, kökeni ve bölgeye nereden geldikleri hususu üzerinde günümüze kadar yapılan araştırmalardan bir netice çıkmış değildir. Bizanslı tarihçi Pachymeres'in Menderes Türklerinin Osman Gazi'ye yardım ettiklerine dair verdiği bilgi, beyliklerin birbirinden bağımsız oldukları algısından dolayı tam olarak anlaşılamamış, XIV. yüzyılın hemen başında Bizans'ın Anadolu tarafındaki topraklarına hızla yayılmış olan Türklerin eski Tapınakçılara karşı Rodos Adası için verdikleri mücadelenin boyutlarının anlaşılması da mümkün olmamıştır. Elinizdeki çalışma, vakıf belgelerinden hareketle Menteşe Bey’in menşeini Yassıçimen Savaşı'ndan sonra Selçukluların hizmetine giren Harzemlilerin lideri Kayır/Kır Han’a bağlarken, beyliğin kurulduğu bölgeye Sakarya nehri havalisinden geldiğini göstermektedir. Onunla beraber Batı Anadolu'nun fethinde önemli roller üstlenen Sasan Bey hakkında yeni önermeler getirilmesini sağlayacak veriler de değerlendirilmiştir. Kayır Han'ın Menteşe Bey'den başka, isimleri tesbit edilen diğer oğulları vasıtasıyla Batı Anadolu beylikler dünyası ve Osmanlıları şahsında birleştirme ihtimali, Moğol İstilâsı ve Yassıçimen Savaşı'ndan sonra devletlerini yitirmiş olan Harzemli bakıyyelerinin, cihanşümul bir devletin kurulmasında başat rol üstlendiklerini düşündürür. Kayır Han'ın baba isminin Nu'man oluşu ise, sadece Karesioğulları'nın değil, beylikler dünyasını teşkil eden yönetici zümrenin büyük çoğunluğunun Danişmendliler ile olan bağlantısını da akla getirmektedir. Çalışma bu yönüyle Batı Anadolu'nun Türkleşmesine yeni bir çerçeve çizme çabasının ilk adımı olarak ele alınmalıdır.

Anahtar Kelimeler: Menteşe Bey, Numan oğlu Kirbey, Kayır Han, Harzemşahlar, Danişmendliler. 


\section{EKLER}

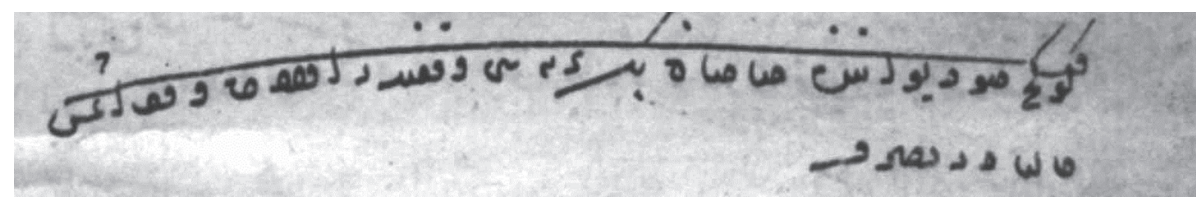

1. TADB. TTD. EV. 547, v. 25a;

Karye-i Gökçesu Divaninda Sasan Bey Türbesi Vakfidır.

Evvelden vakuf imis. Haliya der-tasarruf.

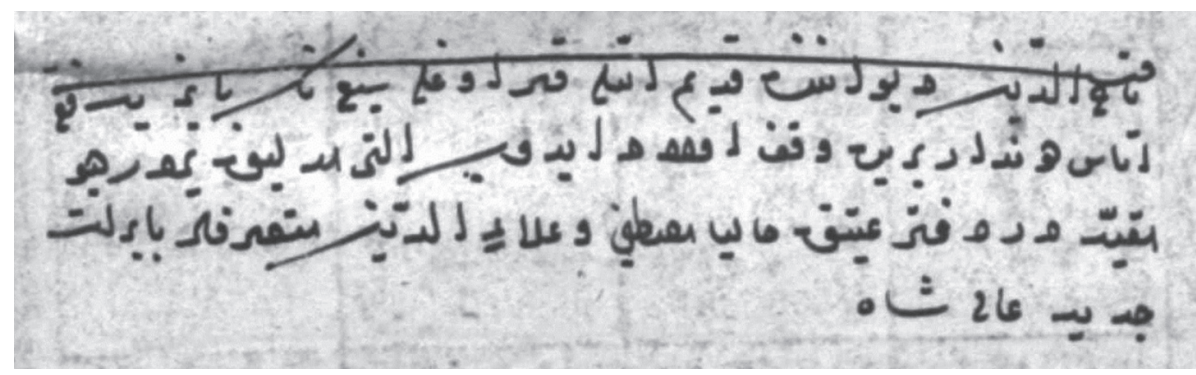

2. TADB. TTD. EV. 547, v. 64b;

Karye-i Taceddin Divaninda kadim-i ıssî Kıroğlu Seyfi Bey, Bayezid Fakı atası

Dündar yerine vakf-ı evlad idüb altı müdlük yerdir deyu mukayyed der-defter-i atik.

Haliya Mustafa ve Alaüddin mutasarriflar ba-berat-ı cedid-i âlişân.

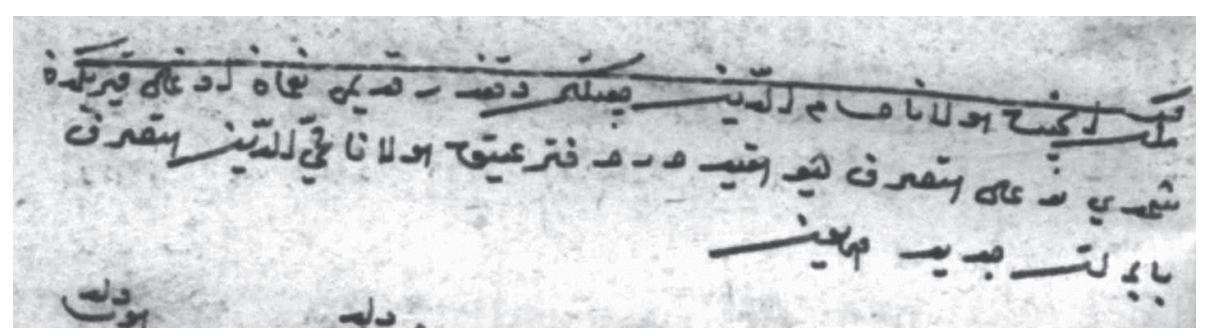

3. TADB. TTD. EV. 547, v. 213a;

Karye-i Mülk içinde Mevlana Hüsameddin Çiftliği vakıfdır kadimî,

Nu’man oğlu Kır Bey'den. Şimdi Bu Ali mutasarrif deyu mukayyed der-defter-i atik. Mevlana Mubiyiddin mutasarrif ba-berât-ı cedid-i hümâyun. 


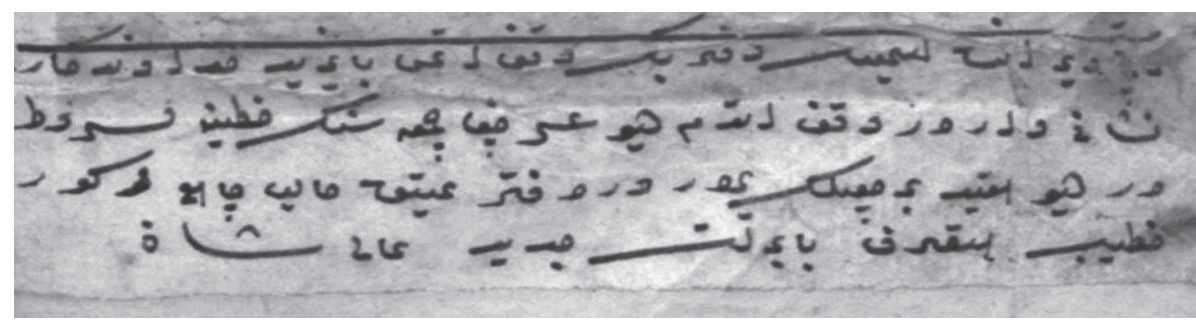

4. TADB. TTD. EV. 547, v. 72b-73a;

Karye-i Akçaviran'da İsmail ve Kır Bey vakfetmiş. Bayezid Hüdâvendigâr nişânı vardır vakfetdüm deyü öşrü Çağa camisinin hatibine meşrûtdur deyü mukayyed bir çiftlik yerdir der defter-i atik. Hâliyâ cami-i mezkûr hatibi mutasarrıf bâ-berat-ı cedid-i âlişân.

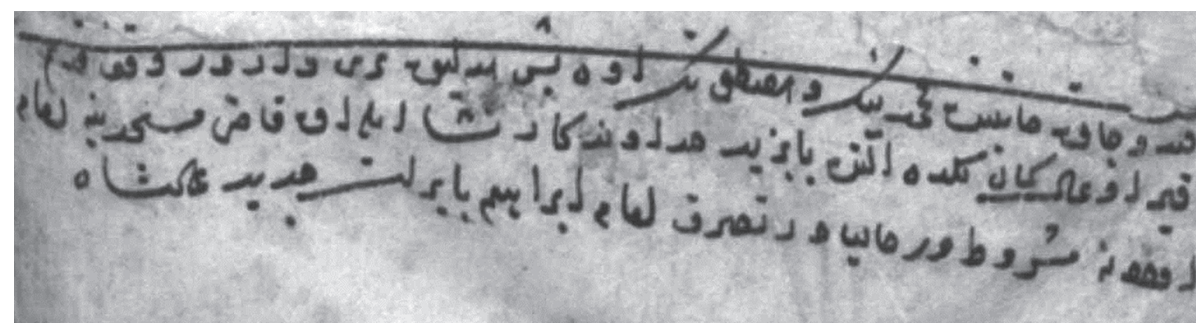

5. TADB. TTD. EV. 547, v. 232b;

Karye-i Fınducak cânibinde Mehmed'in ve Mustafa'nın onbeş müdlük yeri vardır. Vakf-ı kadîm. Kıroğlu Kemal Bey’den elinde Bayezid Hüdâvendigâr nişânı ile Akkadı Mescidi’ne imam olana meşrûtdur. Hâliyâ der tasarruf-1 İmam İbrahim bâ-berât-1 cedid-i âlişân.

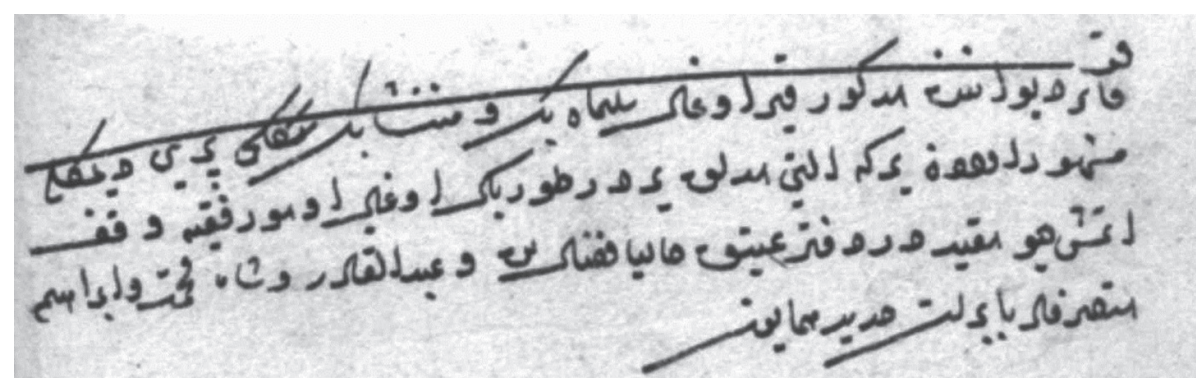

\section{TADB. TTD. EV. 547, v. 93b;}

Karye-i Kayır Divaninda mezkûr Kıroğlu Süleyman Bey ve Menteşe Bey, Beylikçi Yeri dimekle meşhûr olan yer ki altı müdlük yerdir. Turbeyi oğlu Umur Fakı'ya vakfetmiş deyu mukayyed der-defter-i atik. Haliya Fazlullah ve Abdülkadir ve Şah Muhammed ve İbrahim mutasarrıflar ba-berat-ı cedid-i hümâyun. 


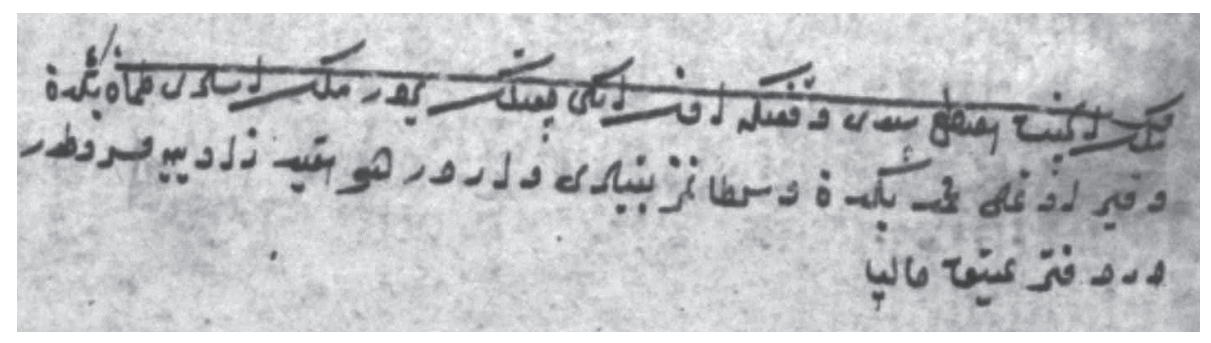

7. TADB. TTD. EV. 547, v. 207a;

Karye-i Mülk içinde Mustafa Seydi Vakfı ki oniki çiftlik yerdir. Mülk-i issîleri Toman/Duman Bey'den ve Kıroğlu Mehmed Bey'den ve Sultanımı bitileri vardır deyu mukayyed der-defter-i atik. Zaviyeye meşrûttur der-defter-i atik, haliya. ${ }^{87}$

\section{Kaynaklar}

\section{Arşiv Belgeleri}

Afyon Müzesi, Kadı Sicilleri, No: 505/144.

Başbakanlık Osmanlı Arşivi (BOA), MAD. 2.

Başbakanlık Osmanlı Arşivi (BOA), TD. 12.

Başbakanlık Osmanlı Arşivi (BOA), TD. 23.

Başbakanlık Osmanlı Arşivi (BOA), TD. 75.

Başbakanlık Osmanlı Arşivi (BOA), TD. 434.

Başbakanlık Osmanlı Arşivi (BOA), TD. 490.

Başbakanlık Osmanlı Arşivi (BOA), TD. EV. 338.

Başbakanlık Osmanlı Arşivi (BOA), TD. EV. 367.

Başbakanlık Osmanlı Arşivi (BOA), TD. EV. 453.

Tapu Arşiv Dairesi Başkanlığı (TADB), TTD. 80.

Tapu Arşiv Dairesi Başkanlığı (TADB), TTD. 156.

Tapu Arşiv Dairesi Başkanlığı (TADB), TTD. EV. 547.

Tapu Arşiv Dairesi Başkanlığı (TADB), TTD. EV. 548.

Tapu Arşiv Dairesi Başkanlığı (TADB), TTD. EV. 554.

87 Bu belge için ayrıca bkz. Vedat Turgut, “Osman Gazi’nin Kimliği Meselesi ve Cihanşümûl Bir

Devlete İsminin Verilmesinin Sebepleri Üzerine”, AID, C. II, S. 1, (Sakarya 2016), s. 107. 
Tapu Arşiv Dairesi Başkanlığı (TADB), TTD. EV. 555.

Tapu Arşiv Dairesi Başkanlığı (TADB), TTD. EV. 560.

Tapu Arşiv Dairesi Başkanlığı (TADB), TTD. EV. 561.

Tapu Arşiv Dairesi Başkanlığı (TADB), TTD. EV. 564.

Tapu Arşiv Dairesi Başkanlığı (TADB), TTD. EV. 569.

Tapu Arşiv Dairesi Başkanlığı (TADB), TTD. EV. 571.

Tapu Arşiv Dairesi Başkanlığı (TADB), TTD. EV. 578.

Tapu Arşiv Dairesi Başkanlığı (TADB), TTD. EV. 580.

Vakıflar Genel Müdürlüğü Arşivi (VGMA), Defter: 618/1, S. 167/129.

Vakıflar Genel Müdürlüğü Arşivi (VGMA), Defter: 990, S. 160/158.

\section{Yayınlanmış Eserler}

Akın, Himmet: Aydınoğulları Tarihi Hakkında Bir Araştırma, Ankara: Ankara Üniversitesi DTCF Yay., 1968.

Âşıkpaşazâde: Tevârih, (Atsız Neşri), İstanbul: Ötüken Yay., 2011.

Ayönü, Yusuf, Katalanlarm Anadolu ve Trakya'daki Faaliyetleri, (1302-1311), İzmir: Ege Üniversitesi Basımevi, 2009.

Azamat, Nihat: "Hacı Bayram Veli", DİA, 14, (İstanbul 1996), s. 442-447.

Barkan, Ö. Lütfi: “Osmanlı İmparatorluğu’nda Bir İskân ve Kolonizasyon Metodu Olarak Vakıflar ve Temlikler I: İstila Devrinin Türk Dervişleri ve Zâviyeleri”, VD, II (1942), s. 279-386.

Baybars: Baypars Tarihi, çev. M. Şerefüddin Yaltkaya, Ankara: TTK Yayınları, 2000.

Cahen, Claude: Osmanlılardan Önce Anadolu'da Türkler, terc. Yıldız Moran, İstanbul: E Yayınları, 1994.

Celâl-zâde Sâlih Çelebi: Hadîkatü's-Selâtîn, haz. Hasan Yüksel, H. İbrahim Delice, Ankara: TTK Yayınları, 2013.

Cüveynî, Alaaddin Ata Melik: Tarih-i Cihan Güşâ, çev. Mürsel Öztürk, Ankara, Türk Tarih Kurumu, 2013.

Danişmend Gazi Destanı, haz. Necati Demir, Ankara: Hece Yayınları, 2006.

Danişmend, İ. Hami: İzahlı Osmanlı Tarihi Kronolojisi, İstanbul: Sümer Kitabevi, I, 1971.

Elvan Çelebi: Menâkıbül-Kudsiyye fi Menâsıbül-Ünsiyye, haz. İsmail E. Erünsal-A. Yaşar Ocak, Ankara: TTK Yayınları, 1995.

Emecen, Feridun M.: İlk Osmanlılar ve Batı Anadolu Beylikleri Dünyası, İstanbul: Timaş Yayınları, 2016. 
Emecen, Feridun M.: Doğu Karadeniz'de İki Kıyı Kasabasının Tarihi, Bulancak-Piraziz, İstanbul: Bahçeşehir Üniversitesi Yayınları, 2015.

Emecen, Feridun M.: Osmanlı Imparatorluğu’nun Kuruluş ve Yükseliş Taribi, 1300-1600, İstanbul: Türkiye İş Bankası Kültür Yayınları, 2015.

Düsturnâme (Haz. M. Halil Yinanç), İstanbul: Devlet Matbaası, 1928.

Enverî: Düstûrnâme, Medhal, (Haz. M. H. Yınanç), İstanbul: Türk Tarih Encümeni Külliyatı, 1932.

Geyikoğlu, Hasan: “Anadolu’da Kalan Harezmliler (Horzumlular)”, Türk Kültürü, 35/410 (1997), s. 51-60.

Gordlevski, W. A.: Anadolu Selçuklu Devleti, çev. Azer Yoran, Ankara: Onur Yayınları, 1988.

Gönçer, Süleyman H.: “Değerli Bir Belge Bir Vakıfnâme”, Afyon Taşpınar Halkevi Mecmuast, 89-91 (1942), s. 110-113.

Gül, Muammer: "Harezmli Türklerin Anadolu ve Yakındoğu'daki Rolleri ve Tesirleri", Belleten, c. LXX/ 257 (2016), s. 95-118.

Hacıgökmen, M. Ali: "I. Alaeddin Keykubat Dönemi Emirlerinden Atabey Bedreddin Gühertaş (Gevhertaş) (D?-Ö. 1262), Ankara Üniversitesi, DTCF Tarih Araştırmaları Dergisi, XXX/50 (2011), s. 119-137.

İbn Battuta: Seyahatnâme, I, çev. A. Sait Aykut, İstanbul: Yapı-Kredi Yayınları, 2000.

İbn Bibi: El-Evâmirü'l-Alầiyye fi'l-Umûri'l-Alâiyye, Selçuknâme, II, çev. Mürsel Öztürk, Ankara: TTK Yayınları, 2014.

İnalcık, Halil: Kuruluş Dönemi Osmanlı Sultanları, İstanbul: İSAM Yayınları, 2010.

Jorga, Nicolae: Osmanlı İmparatorluğu Tarihi, çev. Nilüfer Epçeli, İstanbul: Yeditepe Yayınları, 2005, V.

Karaca, Behset: XVI. Yüzyılda Teke Sancă̆g, Isparta: Fakülte Kitabevi, 2002.

Kılıç, Mustafa: “Celaleddin Harizmşah'tan Sonra Anadolu ve Suriye'de Harizmliler”, Eyyübiler, (Yönetim, Diplomasi, Kültürel Hayat), ed. Önder Kaya, İstanbul: Küre Yayınları, 2012, s. 231-247.

Kofoğlu, Sait: Hamidoğulları Beyliği, Ankara: TTK Yayınları, 2006.

Köprülü, M. Fuat: "Harzemşahlar”, İ, V/I, (İstanbul 1977), s. 290-292.

Köprülü, M. Fuat: Osmanlı Devletinin Kuruluşu, Ankara: TTK Yayınları, 1991.

Mehmed Neşri: Cihannüma, I, haz. F. R. Unat-M. A. Köymen, Ankara: TTK Yayınları, 1995.

Merçil, Erdoğan: “Menteşeoğulları”, Dİ, 29, (Ankara 2004), s. 152.

Muhammed b. Turtûşî: Siracül-Mülûk, haz. Said Aykut, İstanbul: İnsan Yayınları, 2005. 
Ocak, A. Yaşar: Babailer İsyanı, Aleviliğgin Tarihsel Alt Yapısı Yahut Anadolu'da İslam-Türk Heterodoksisinin Teşekkülü, İstanbul: Dergâh Yayınları, 2011.

Ocak, Ahmet Yaşar: Ortaçă̆ Anadolu’sunda İki Büyük Yerleşimci (Kolonizatör) Yahut Vefâiyye ve Yeseviyye Gerçeği: Dede Garkın ve Emirci Sultan (13. Yüzyıl), Ankara: Gazi Üniversitesi Yay., 2011.

Pachymeres: Bizanslı Gözüyle Türkler, haz. İ. Biter Barlas, İstanbul: İlgi Yayınları, 2009.

Pitcher, Donald Edgar: Osmanlı İmparatorlü̆u’nun Tarihsel Coğrafyası, çev. Bahar Tirnakçı, İstanbul: Yapı Kredi Yayınları, 1999.

Runciman, Steve: “Anadolu’nun Ortaçağlardaki Rolü”, Belleten, VII/27 (1943), s. 550.

Şahin, İlhan: "Kırşehir”, DİA, 25, (Ankara 2002), s. 481-484.

Şihabeddin b. Fazlullah el-Ömerî: Türkler Hakkında Gördüklerim ve Duyduklarım, Mesâlikül-Ahbar, çev. D. Ahsen Batur, İstanbul: Selenge Yayınları, 2014. krş. için İbn Fadlullah el-Ömeri, Mesâlikül-Ebsâr fî Memâliki'l-Emsâr, III, thk. Kâmil Süleyman el-Cubûrî, Beyrut: Dar Al-Kutub Al-İlmiyah, 2010.

Turan, Osman: Selçuklular Zamanında Türkiye, İstanbul: Boğaziçi Yayınları, 1998.

Turgut, Vedat: "Vakıf Belgeleri Işı̆̆ında Umur Bey ve Lala Şahin Paşa’nın Menşei ve Osmanlılar ile İttifakına Dair”, Osmanlı Araştırmaları, 47 (İstanbul 2016), s. 1-38.

Turgut, Vedat: "Batı Anadolu Beyliklerinin Menşei Meselesi”, Sakarya Üniversitesi Sosyal ve Kültürel Araştırmalar Dergisi, 2/3, (2016), s. 55-89.

Turgut, Vedat: "Osman Gazi'nin Kimliği ve Cihanşümûl Bir Devlete İsminin Verilmesinin Sebepleri Üzerine”, Akademik İncelemeler Dergisi, II/1 (2016), s. 83-120.

Turgut, Vedat: Yitirilen Mirasımı:: Balkanlarda Kurulan Osmanlı Vakıfları (Fethinden XVI. Yüzyılın Sonuna Kadar), Eskişehir: Türk Dünyası Vakfı Yayınları, 2016.

Turgut, Vedat: Osmanlı Devleti’nin Kuruluş Coğrafyasinda Vakıflar ve Şehirleşme (16. yy. Bilecik ve Çevresi), Bilecik: Bilecik Şeyh Edebâli Üniversitesi Yayınları, 2015.

Uzunçarşılı, İ. Hakkı: “Menteşeoğulları”, İA, VII, s. 724-731.

Uzunçarşılı, İ. Hakkı: Anadolu Beylikleri ve Akkoyunlu, Karakoyunlu Devletleri, Ankara: TTK Yayınları, 2011.

Uzunçarşılı, İ. Hakkı: Anadolu Türk Tarihi Vesikalarından II. Kitap, Kitabeler, İstanbul: Devlet Matbaası, 1347-1929.

Uzunçarşılı, İ. Hakkı: Osmanlı Tarihi, I, Ankara: TTK Yayınları, 2015.

Varlık, M. Çetin: Germiyanoğulları Tarihi, Ankara: Sevinç Matbaası, 1974.

Vertot: Historie de Chevaliers Hospitaliers, Paris, 1737, II, s. 101 vd.; 1772 baskısı için bkz. https://books.google.com.tr/books?id=HF9WAAAAYAAJ\&printsec=frontcover\&d $\mathrm{q}=$ Histoiredes + Chevaliers + Hospitaliers $+\mathrm{de}+\mathrm{S} .+\mathrm{Jean}+\mathrm{de}+\mathrm{J} \% \mathrm{C} 3 \%$ A9rusalem + volum 
e+2\&hl=fr\&sa=X\&ved=0ahUKEwj Fw8i3zrDQAhULax QKHfJ_ASYQ6AEIPzA $\mathrm{E} \# \mathrm{v}=$ onepage $\& \mathrm{q} \& \mathrm{f}=$ false.

Wittek, Paul: Menteşe Beyliği, çev. O. Ş. Gökyay, Ankara: TTK Yayınları, 1999.

Yazır, Elmalılı Hamdi: Kur'an-ı Kerîm ve Meâli, haz. Dücane Cündioğlu, İstanbul: İslamoğlu Yayıncılık, 1993.

Yiğit, Ahmet: XVI. Yüzyıl Menteşe Livası Vakıfları, Ankara: Barış Platin, 2009.

Zachariadou, Elizabeth: "The Catalans of Athens and the Beginning of the Turkish Expansion in the Aegean Area", Studi Mediavali, XXI/3, 1980, s. 821-838; krş. için Zachariadou, "Atina Katalanları ve Ege Bölgesinde Türk Yayılmasının Başlaması", çev. Serdar Çavuşdere, TAD, 45/(2009), s. 235-254.

Ziver Bey: Rodos Tarihi, çev. Harid Fedai, Ankara: TTK Yayınları, 2013. 